\title{
Edifice growth, deformation and rift zone development in basaltic setting: Insights from Piton de la Fournaise shield volcano (Réunion Island)
}

\author{
Laurent Michon $^{\mathrm{a}, *}$, Valérie Cayol ${ }^{\mathrm{b}}$, Ludovic Letourneur ${ }^{\mathrm{c}}$, Aline Peltier ${ }^{\mathrm{d}}$, \\ Nicolas Villeneuve ${ }^{\mathrm{e}}$, Thomas Staudacher ${ }^{\mathrm{f}}$ \\ a Laboratoire GéoSciences Réunion, Université de la Réunion, Institut de Physique du Globe de Paris, CNRS, UMR 7154 - Géologie des Systèmes Volcaniques, 15 avenue René Cassin, \\ 97715 Saint Denis, France \\ ${ }^{\mathrm{b}}$ Laboratoire Magmas et Volcans, UMR 6524, CNRS-IRD-Université Blaise Pascal, 5 rue Kessler, 63038 Clermont-Ferrand, France \\ c Department of Structural Geology and Geodynamics, Geoscience Centre, University of Göttingen, Goldschmidtstrasse 3, D-37077 Göttingen, Germany \\ ' Institut de Physique du Globe de Paris, CNRS, UMR 7154 - Géologie des Systèmes Volcaniques, 4 place Jussieu, 75252 Paris cedex 05, France \\ e Institut de Recherche pour le Développement, US 140, BP172, 97492 Sainte-Clotilde cedex, France \\ ${ }^{\mathrm{f}}$ Observatoire Volcanologique du Piton de la Fournaise (OVPF), Institut de Physique du Globe de Paris, CNRS, UMR 7154 - Géologie des Systèmes Volcaniques, \\ 97418 La Plaine des Cafres, France
}

The overall morphology of basaltic volcanoes mainly depends on their eruptive activity (effusive vs. explosive), the geometry of the rift zones and the characteristics of both endogenous and exogenous growth processes. The origin of the steep geometry of the central cone of Piton de la Fournaise volcano, which is unusual for a basaltic effusive volcano, and its deformation are examined with a combination of a detailed morphological analysis, field observations, GPS data from the Piton de la Fournaise Volcano Observatory and numerical models. The new caldera walls formed during the April 2007 summit collapse reveal that the steep cone is composed of a pyroclastic core, inherited from an earlier explosive phase, overlapped by a pile of thin lava flows. This suggests that exogenous processes played a major role in the building of the steep central cone. Magma injections into the cone, which mainly occur along the N25-30 and N120 rift zones, lead to an asymmetric outward inflation concentrated in the cone's eastern half. This endogenous growth progressively tilts the southeast and east flanks of the cone, and induces the development of a dense network of flank fractures. Finally, it is proposed that intrusions along the N120 rift zone are encouraged by stresses induced by magma injections along the N25-30 rift zone.

\section{Introduction}

Basaltic shield volcanoes grow by the combined effect of endogenous and exogenous processes (e.g., Annen et al., 2001). Endogenous growth is mainly related to dyke intrusions, which preferentially propagate along the existing rift zones. The volcano shape consequently depends on the intensity of their activity and may vary from elongated, e.g., Karthala in Grande Comore, and Mona Loa and Kilauea in Hawaii, to sub-circular, e.g., volcanoes of Western Galapagos. Exogenous growth results from the accumulation of lava flows and pyroclastic cones (Naumann and Geist, 2000; Rowland and Garbeil, 2000). Long lava flows tend to flatten the volcano morphology, whereas short and thick ones may encourage the development of steep edifices (Naumann and Geist, 2000; Annen et al., 2001).

At Piton de la Fournaise, Réunion Island, however, the magmatic activity led to the development of a steep central cone in the Enclos caldera despite the predominance of fissure eruptions that feed fluid

\footnotetext{
* Corresponding author. Tel.: +33 2622629382 04; fax: +33 262262938266 . E-mail address: laurent.michon@univ-reunion.fr (L. Michon).
}

basaltic lava flows. Moreover the cone is almost circular whereas most of the eruptions develop along the N25-30 and N120 rift zones (Fig. 1; Michon et al., 2007a). To answer these paradoxes, Annen et al. (2001) proposed, using numerical models, that the geometry of the cone was resulting from a predominant endogenous growth with only $30 \%$ of the edifice volume directly related to short lava flows. Although the models roughly fit the current cone's geometry, the input and natural data partly disagree. First, the simulated dykes (mean thickness of $3 \mathrm{~m}$ ) are not as thick in nature as in the models. Indeed, recent works showed that the mean dyke thickness related to the post-1997 eruptions was around 0.5-0.7 m (Fukushima, 2005; Peltier et al., 2007). Second, the model of Annen et al. (2001) simulates 10,000 dyke intrusions, 7\% of them leading to an eruption. Such an intrusion/eruption ratio is the opposite of that observed since 1972, 81 eruptions (92\%) and 7 intrusions (8\%). Models with more realistic parameters show that the central cone should be much flatter (Annen et al., 2001).

This paper aims at understanding the origin of the atypical geometry of the central cone of Piton de la Fournaise. It examines the morphology and inner structure of the cone. It also considers the role of the magmatic and volcano-tectonic structures in both the growth and the deformation 


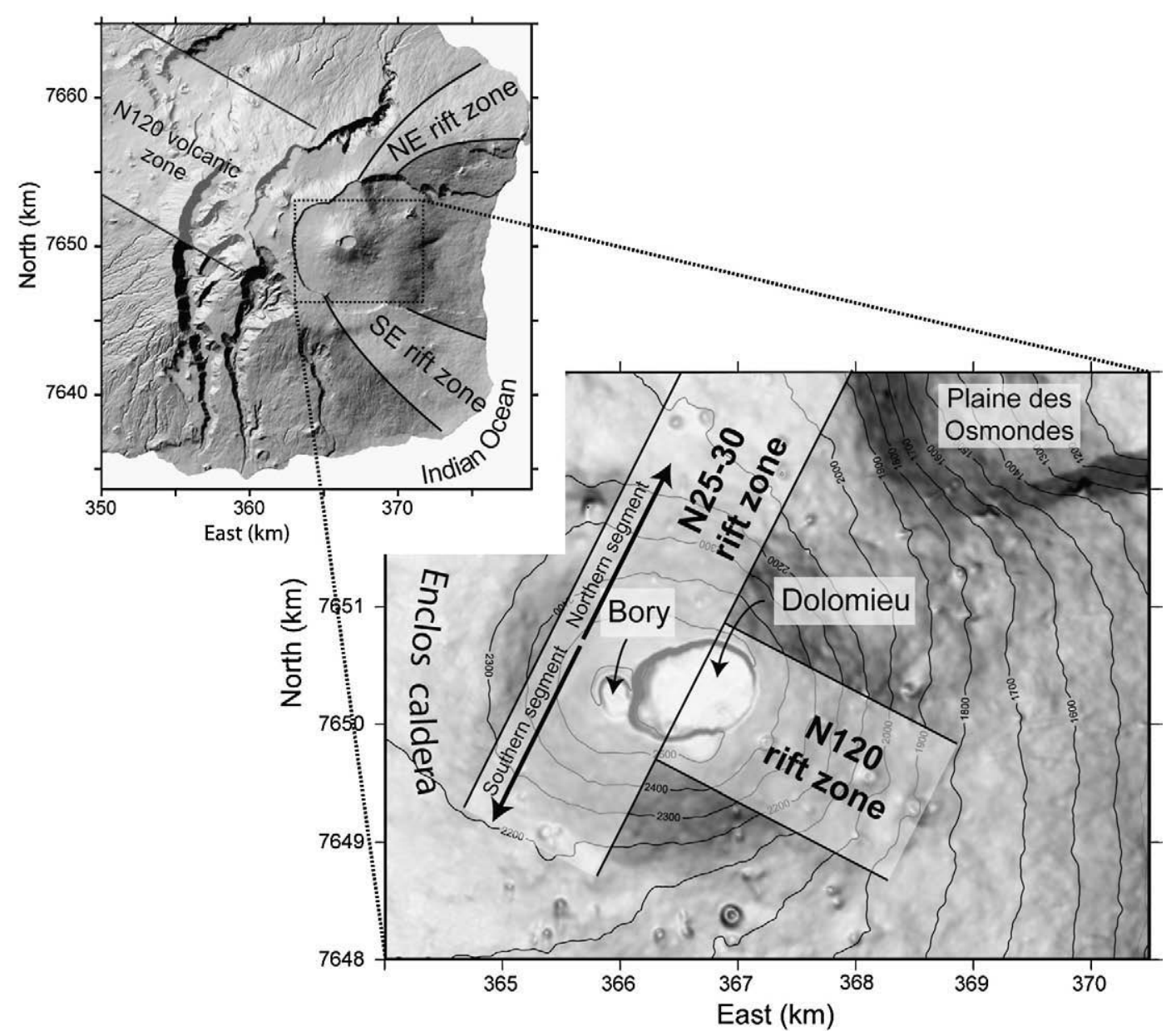

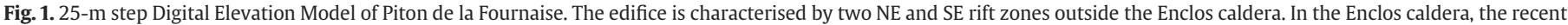

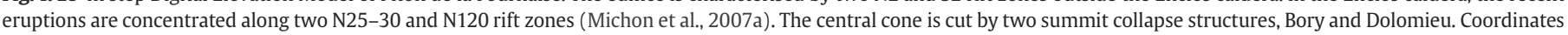
in UTM WGS84 (zone 40S).

of the cone, by combining field data and GPS data, as well as numerical models of rift dyke intrusions. Such a multi-disciplinary approach highlights the existing links between the deformation observed in the field, the displacement measured by GPS, and the recurrent intrusions of the dykes along preferential paths. The origin of the central cone and its deformation are interpreted in the light of both endogenous and exogenous growths.

\section{Morphology and inner structure of the central cone}

Piton de la Fournaise is the active volcano of Réunion Island (Fig. 1). The eruptive centre is located in the upper part of a large Ushaped caldera, the Enclos-Grand Brûlé structure, where most of the eruptions have occurred in the past 4.5 ka (Bachèlery, 1981). The concentration of activity in the upper part of the caldera led to the construction of a 400-m-high cone. Magma intrusions, which originate from a magma chamber located at about sea level below the cone (Peltier et al., 2007), are concentrated along two N25-30 and N120 rift zones (Fig. 1; Michon et al., 2007a). Outside the Enclos caldera, magma intrusions may continue along the NE and SE rift zones. The present-day cone summit shows two collapse structures: Bory crater in the West, which is currently inactive, and Dolomieu in the East, which experienced a caldera collapse during the large April 2007 eruption (Fig. 1; Michon et al., 2007b). Before this collapse, the elongated shape of the pre-existing Dolomieu was the result of the coalescence of several pit craters (Lénat and Bachèlery, 1990; Carter et al., 2007). As a whole, Bory and Dolomieu confer a global E-W elongation to the summit of the central cone.

The use of a 25-m step digital elevation model (DEM) provided by the Institut Géographique National allows a precise description of the limits of the cone, the distribution of the slopes and the structure of the summit zone. The cone's lower limit corresponds to an almost continuous sharp break-in-slope that separates the caldera floor and the steep flanks of the cone (Fig. 2). The local outlined discontinuities are due to the Puy Mi-Côte parasitic cone in the North, and the N120 topographic ridge in the SE, which is formed by the alignment of large pyroclastic cones along the N120 rift zone. These two structures disregarded, the base of the cone presents a sub-circular shape with a radius of about $1.6 \mathrm{~km}$ (Fig. 2a). The flanks of the cone present steep slopes, which contrast with the classical view of a basaltic effusive edifice. The western part of the cone, i.e., west of a N15-trending line centred on Dolomieu, is characterised by relatively homogeneous slopes ranging between $15^{\circ}$ and $25^{\circ}$. East of the N15 boundary, the cone shows steeper slopes $\left(25-30^{\circ}\right)$, which locally reach $35^{\circ}$. Although the N120 topographic ridge gives to the southeast flank a complex slope distribution, the low-pass filtered DEM strikingly shows that the steep slopes of the cone's eastern half are not circumferentially distributed, but present two linear trends in the N150 and N55 directions (Fig. 2b). It is noteworthy that the N55 trend is aligned with a 500-m-wide and 700-m-long zone characterised by a network of parallel lineaments (Fig. 2c). Field observations and aerial photographs reveal that the lineaments correspond neither to the limit of lava flows, nor to eruptive 
fissures. Therefore, it is likely that the lineaments coincide to the surface trace of a fault zone, the activity of which may be related to the dynamics of the magmatic system. Finally, the summit morphology of the cone is characterised by present collapse structures, Bory and Dolomieu, surrounded by relatively flat areas which were interpreted as fully filled pit craters (Fig. 2b; Bachèlery, 1981; Lénat and Bachèlery, 1990). Past and present collapse structures are restricted to a slightly elongated zone, the centre of which is nearly superimposed to that of the $3.2 \mathrm{~km}$-across circle marking the base of the cone (Fig. 2b).

The April 2007 caldera, which deeply cut the central cone, formed new scarps that reveal its internal structure (Fig. 3). The northern and southern caldera walls exhibit three main structural features:

(1) The northwestern part of the cone built up above a pre-Bory pit crater, the existence of which was already hypothesised by Lénat and Bachèlery (1990) from the occurrence of gentle slopes north of Bory (Figs. 2b and 3a). The limits of this collapse structure are underlined in the caldera wall by a strong lithological contrast characterised by thick lava units, and the succession of thin lava flows and scoria layers, inside and outside the pit respectively.

(2) The volcanic units cut by the pre-Bory pit crater are subhorizontal and parallel to the present day surface, suggesting that the current geometry of the cone is inherited from a stage predating the development of the pre-Bory pit crater. This evolution disagrees with the historical reports of the 18th and 19th centuries in which the cone is considered to be symmetric and centred on the Bory pit crater until 1760, and becoming asymmetric when the activity shifted to the east flank of the cone in 1766 (Bory de Saint-Vincent, 1804).

(3) The caldera walls reveal a relatively constant lithological pile with a succession of scoria and scoria-rich units underneath a pile of thin lava flows (Fig. 3). The scoria materials suggest a period of predominantly explosive activity, which probably led to the construction of a large pyroclastic cone.

\section{Fractures of the central cone}

During the last decades, several works have addressed the origin of the tectonic structures of the central cone (Bachèlery, 1981; Bachèlery et al., 1983; Lénat and Bachèlery, 1990; Carter et al., 2007). The different analyses, which were essentially or strictly restricted to the summit of the central cone, revealed the coexistence of concentric and radial volcano-tectonic structures, consisting mainly of extensional fractures and eruptive fissures, respectively. The concentric fractures are restricted within the first tens of meters from the rim of Dolomieu and Bory. Their formation is interpreted as related to the current and paleo pit crater development, and the dynamics of the superficial magma chamber. Only one fracture network which trends obliquely to the northeast rim of Dolomieu, is linked to another process, i.e., the slumping of the eastern flank (Carter et al., 2007). The volcanotectonic structures described on the flanks of the central cone correspond to eruptive fissures, which usually present a radial strike and open en échelon during dyke injection. This distribution locally changes in the east flank where the eruptive fissures mimic conjugate systems (Carter et al., 2007). The en échelon distribution on the northern and southern flanks of the central cone was initially interpreted as indicative of co-intrusive left-lateral and right-lateral displacements in the respective flanks, causing the eastward motion of the eastern flank of Piton de la Fournaise (Bachèlery et al., 1983). However, Michon et al. (2007a) recently showed that the en échelon pattern most likely resulted from a reorientation of the magma intrusion close to the surface due to the rotation of the main principle stress $\sigma_{1}$ from vertical to downslope, rather than a shear deformation during dyke intrusion.

Since the last structural work at the cone scale in 1990, Piton de la Fournaise underwent 27 eruptions and 3 intrusions, each of them leading to deformation of the summit zone. A new structural analysis was realised on the central cone and the adjacent Enclos floor in order to determine if tectonic structures developed and accommodated the deformation measured from GPS and interferometry (Briole et al., 1998; Sigmundsson et al., 1999; Froger et al., 2004; Fukushima et al., 2005). Our field observations reveal a wide range of fractures affecting the eruptive system. In a way similar to Carter et al. (2007), the present work only considers the fractures cutting at least two adjacent geological units. Fractures restricted to single lava flows or cones, and related to their own dynamics, such as the syn-cooling subsidence or collapse, were disregarded. According to the fracture geometry, size and relationship with the geological formations, three different types of volcano-tectonic structures were distinguished, among which the two first correspond to the radial and concentric fractures already described by Bachèlery et al. (1983) and Carter et al. (2007):

(1) Eruptive fissures mainly open perpendicular to the slope (Fig. 4a). Their mean length inferred from 68 post-1997 eruptive fissures is $180 \mathrm{~m}$. Only few eruptive fissures are oblique to the slope. Their length is significantly higher (i.e., 2.5 to 11 times longer) than that of the downslope eruptive fissures. They are located in the SSE and east flanks of the cone, where they strike N20-25 and N65 respectively. In the east flank, the recent N65trending eruptive fissure of the August 2004 eruption is connected to the southeastern corner of Dolomieu. Aerial photographs of 1936 reveal that older eruptive fissures developed at the same location with a similar geometry. The geometric association of the N65 eruptive fissures with the radial ones forms the conjugate-like systems described by Carter et al. (2007). Occurrence of long and oblique eruptive fissures in the flanks suggests that besides the sub-surface downslope $\sigma_{1}$, which controls the orientation of most of the eruptive fissures (Michon et al., 2007a), local stress fields or structures may influence the magma migration through the east flank. The local structural control is corroborated by the development of N80 and N50 eruptive fissures close to the southern rim of Dolomieu and northwest of Bory, respectively. Indeed, their orientation is parallel to the southern fault of Dolomieu and at the limit of the pre-Bory pit-crater.

(2) Concentric fractures consist in tens to hundreds of metres long extensional fractures either parallel to the scarps of Bory and Dolomieu (Fig. 5a), or at the limit of paleo pit craters. Fracture width evolves from few centimetres to 1-2 $\mathrm{m}$ close to the limits of the pit-craters. The maximum fracture density is observed in Bory, southwest and north of Dolomieu and at the limit of Petit Plateau. Carter et al. (2007) recently proposed that these concentric fractures result from annular extension related to pit-crater collapses. Analysis of the fractures before and after the April 2007 caldera reveals that most of the fractures form during the collapse events and are reactivated by radial extension stresses during the filling of the collapse structure (Michon et al., 2009-this issue).

(3) The third type of fracture corresponds to linear structures that usually affect several geological units, i.e., lava flows or pyroclastic cones. They differ from concentric fractures either

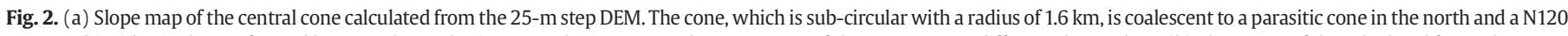

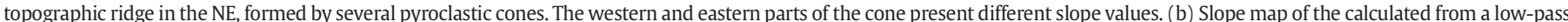

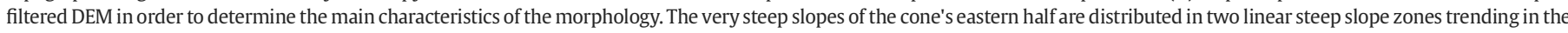

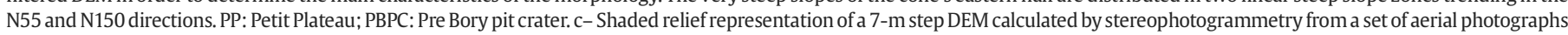

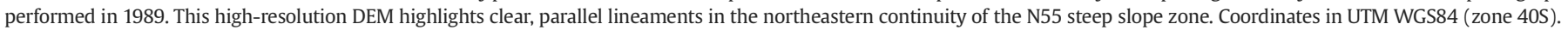



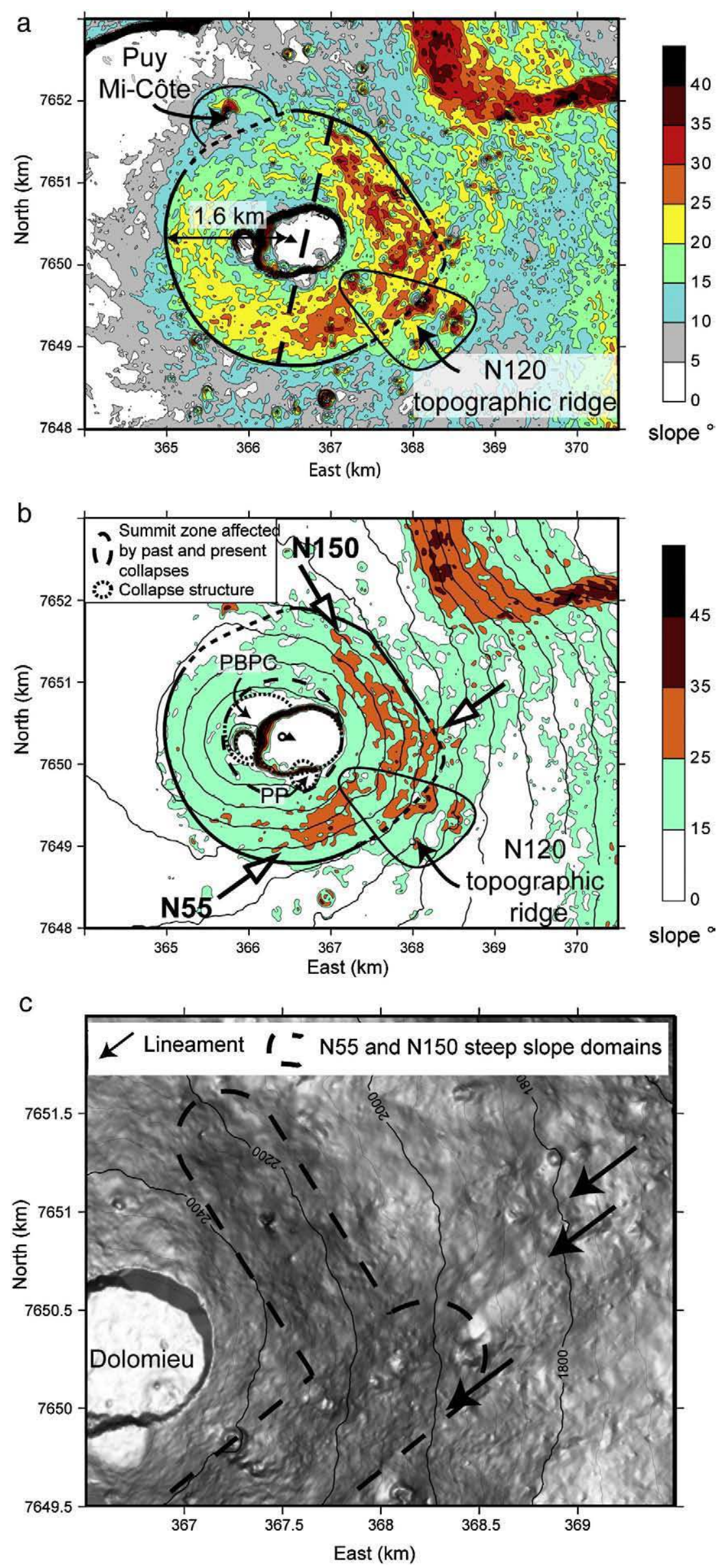


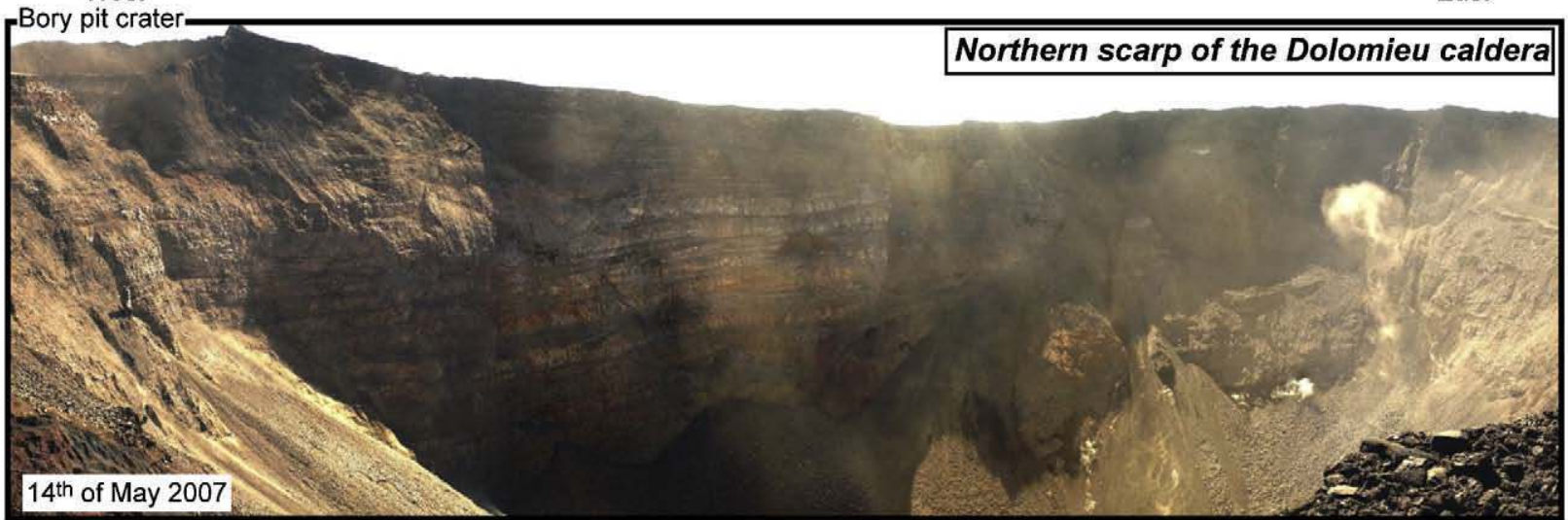

West

East

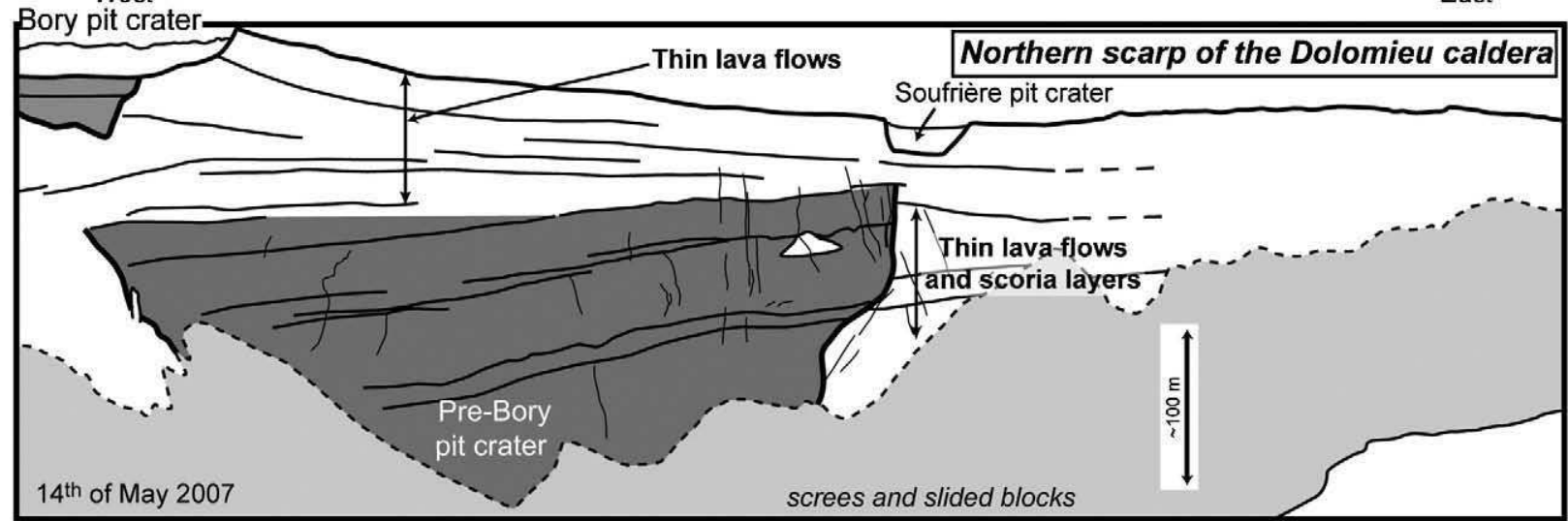

b

Bory pit crater
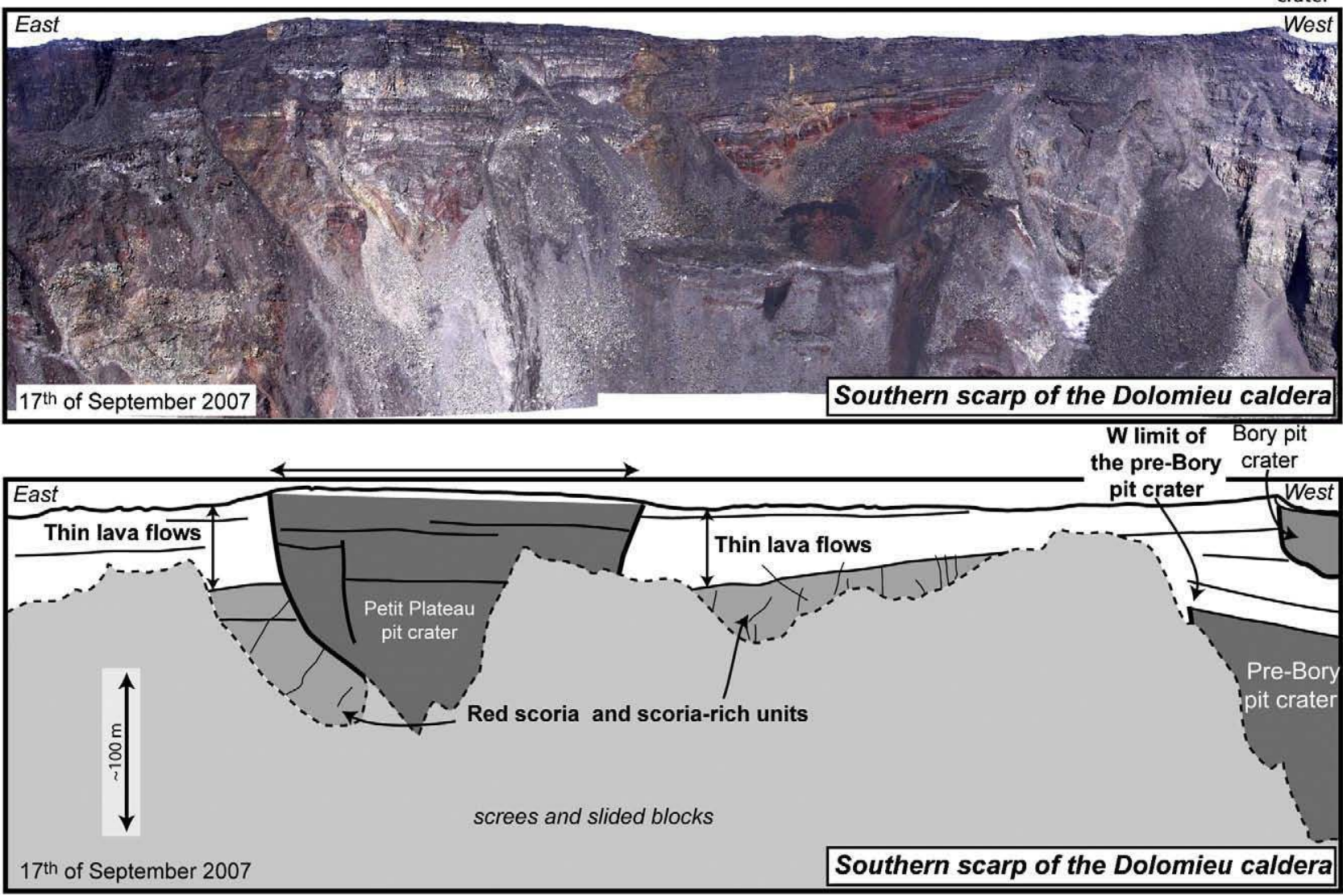

Fig. 3. Panoramas and interpretations of the northern (a) and southern (b) scarps of the April 2007 caldera (photo b: Frederic Massin). 

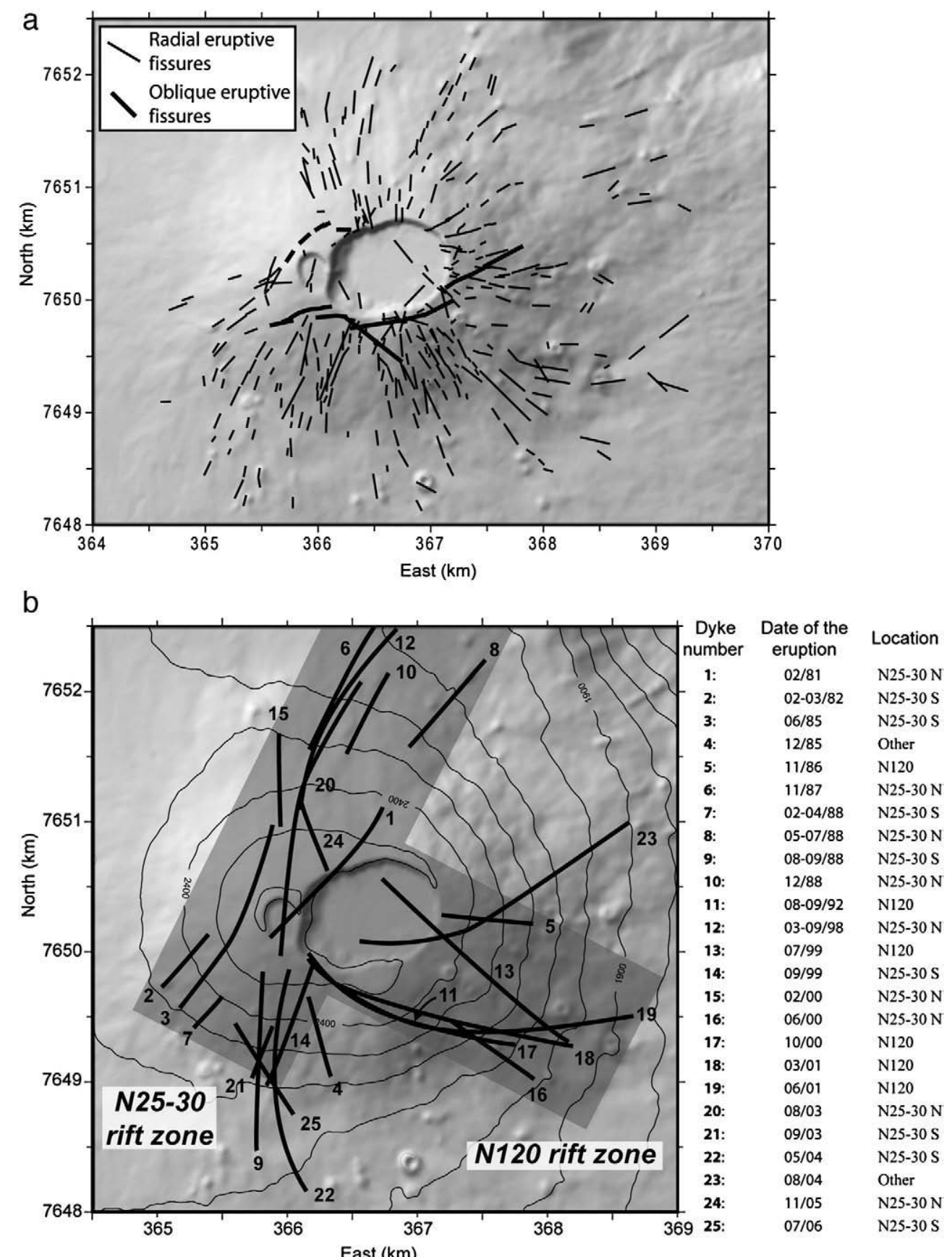

Fig. 4. (a) Distribution of the eruptive fissures. (b) List and location of the dykes associated to proximal eruptions since 1981. Coordinates in UTM WGS84 (zone 40S).

by the distance to the collapse structures or by their obliquity with respect to the concentric faults. Here they are named flank fractures even though some of them are located close to the summit or in the Enclos caldera floor. Two distinct geometries were observed in the field. They correspond to (i) several tens of meters long single linear structures or (ii) 10-50 m wide tectonic corridors in which parallel fractures are concentrated (Fig. 5b). Whatever their geometry, all the fractures are extensive structures showing a slight lateral component in few cases. Systematic mapping of fractures on both the central cone and the proximal part of the Enclos caldera floor shows a strongly heterogeneous spatial distribution (Fig. 6a). Most of the fractures are located in the eastern half of the central cone. They are characterised by three main orientations trending in the N20-30, N55-65 and N150-160 directions. It is remarkable that each trend presents a specific spatial distribution (Fig. 6b). All N20-30-trending fractures are situated east of the N25-30 rift zone. The N55-65 fracture network is concentrated along a main axis, which corresponds to the locus of the clear northeast-trending lineaments northeast of the N55 steep slope zone (Fig. 2c). The continuity of the fractures affecting the old lava units in the August 2004 pahoehoe lava flow, and the decreasing opening of the fractures as a function of the age of the lava flow, suggest a continuous deformation process. Finally, N150-160 fractures are mainly located in the northeastern part of the summit (Fig. 6b). These fractures are concentrated between the eastern rim of Dolomieu and the top of the N150-trending steep slope zone in the northeastern flank. Most of the deformation is restricted to two parallel tectonic corridors of 


\section{a}
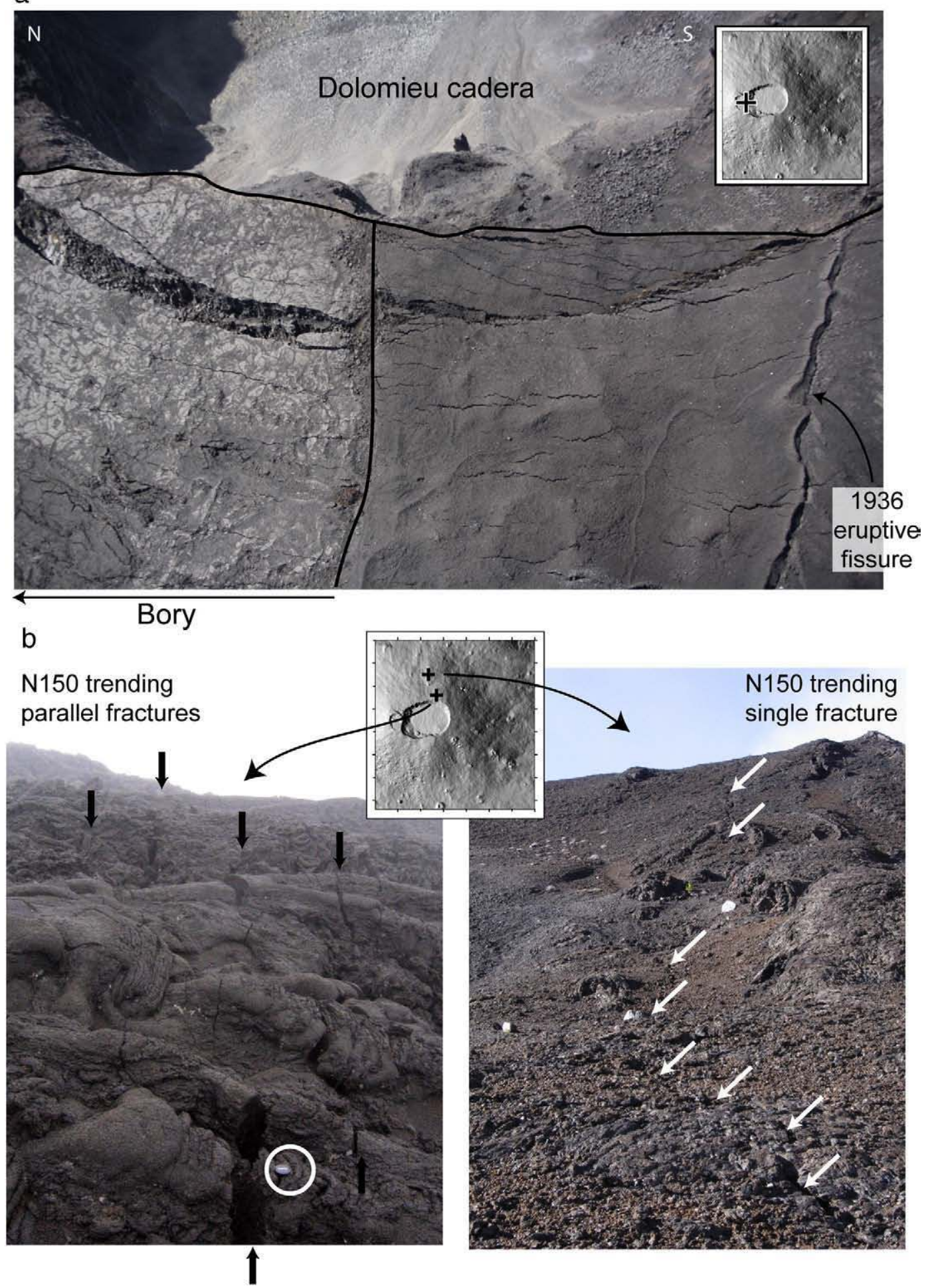

Fig. 5. (a) Picture of the concentric fractures associated to the collapse structures. (b) Pictures of the flank fractures that affect the eastern half of the central cone. Here, the N150 deformation zone.

around 450 and $640 \mathrm{~m}$ long in which fractures indicate an almost exclusive extension. Only a small part of these deformation zones corresponds to the N150 R' shear network described by Carter et al. (2007). Contrary to these authors, we believe that the shear indicators and the lava tube offsets, which suggest minor opposite lateral displacements, result from small differential movements between the lava blocks during a general extension rather than a succession of opposite senses of shear.

\section{Co-intrusive deformation}

4.1. Types of eruptions and the related magmatic paths

Activity of Piton de la Fournaise is characterised by fissure eruptions fed by a magma reservoir located at about sea level (Nercessian et al., 1996; Peltier et al., 2007). Considering the location of the eruption site, three types of eruptions can be distinguished (Peltier et al., 2008): (1) Summit eruptions that start and remain in Dolomieu. (2) Proximal 
a

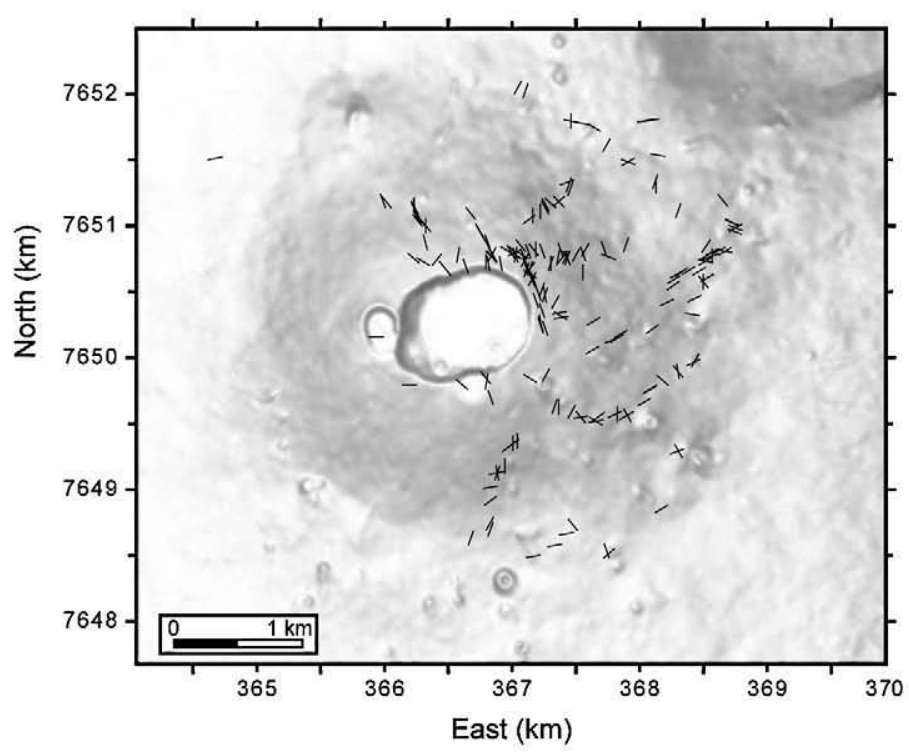

b

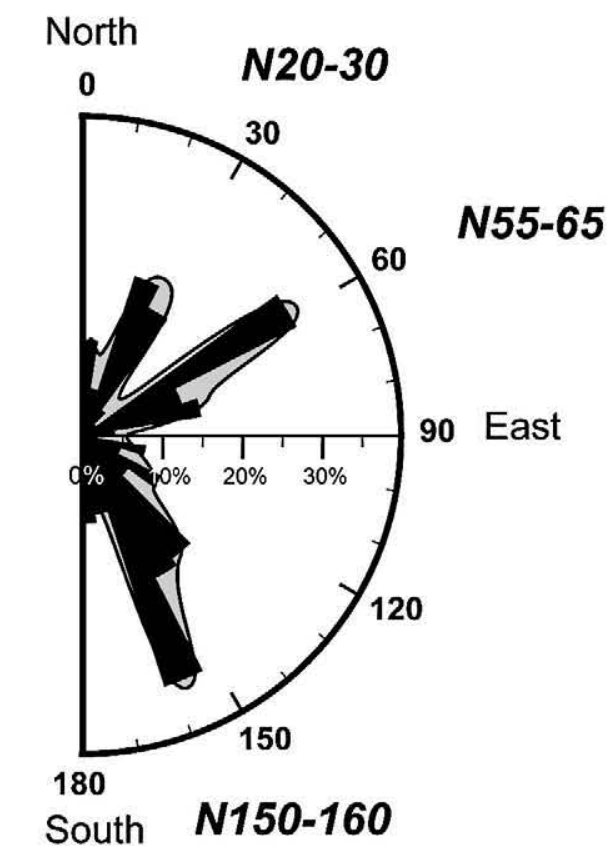

Data: 251 fractures
C
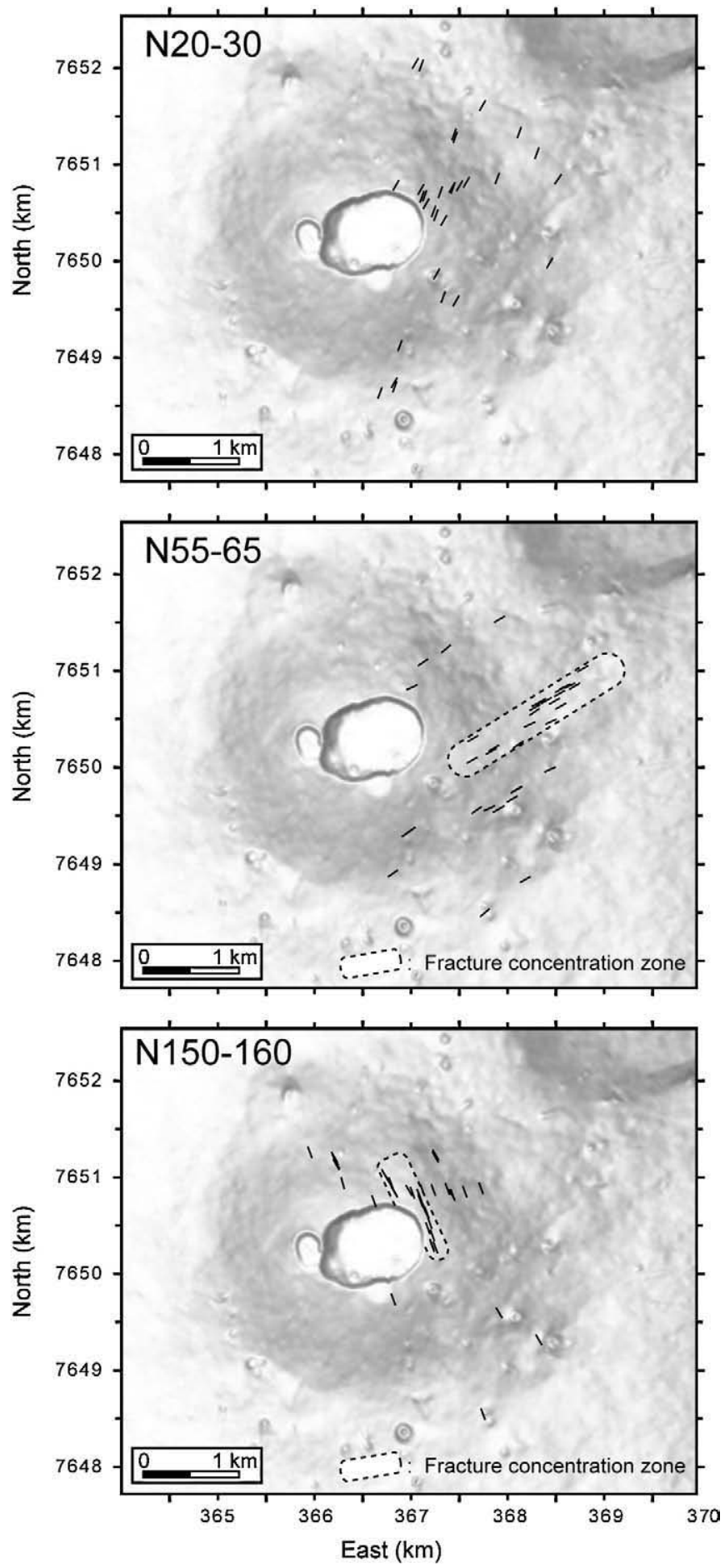

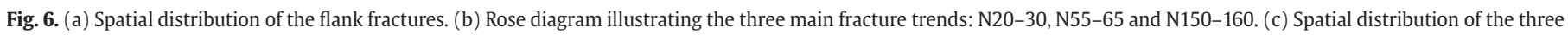
main fracture trends. Coordinates in UTM WGS84 (zone 40S).

eruptions, which may start in the summit but progress to the flanks of the central cone and usually propagate downslope to the Enclos caldera floor. (3) Distal eruptions that develop away from the central cone, starting in the Enclos caldera floor. Numerical models suggest that the elevation of the first eruptive fissure, which opens during an eruption corresponds to the maximum elevation reached by the feeding dyke (Fukushima, 2005; Peltier et al., 2007). Then, only the dykes related to summit and proximal eruptions (68\% of the total eruptions) intrude into the central cone. We determined the dyke orientations related to the 25 proximal eruptions from the distribution of the related eruptive fissures for the period between 1981 and 2007 (Fig. 4b). Note that summit eruptions were disregarded since their dyke orientation cannot be accurately determined. Our compilation shows that $92 \%$ of the proximal dykes follow the N25-30 and N120 rift zones described by Michon et al. (2007a). 74\% of them occur along the N25-30 axis with the same number of dyking events to the North and the South, and $26 \%$ of the eruptions developed on the SE flank along the N120 rift zone (Fig. 4b). 
Table 1

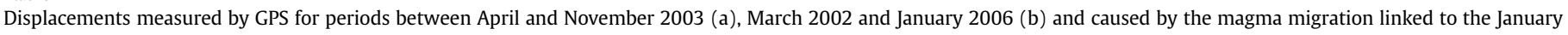
2004 distal eruption (c).

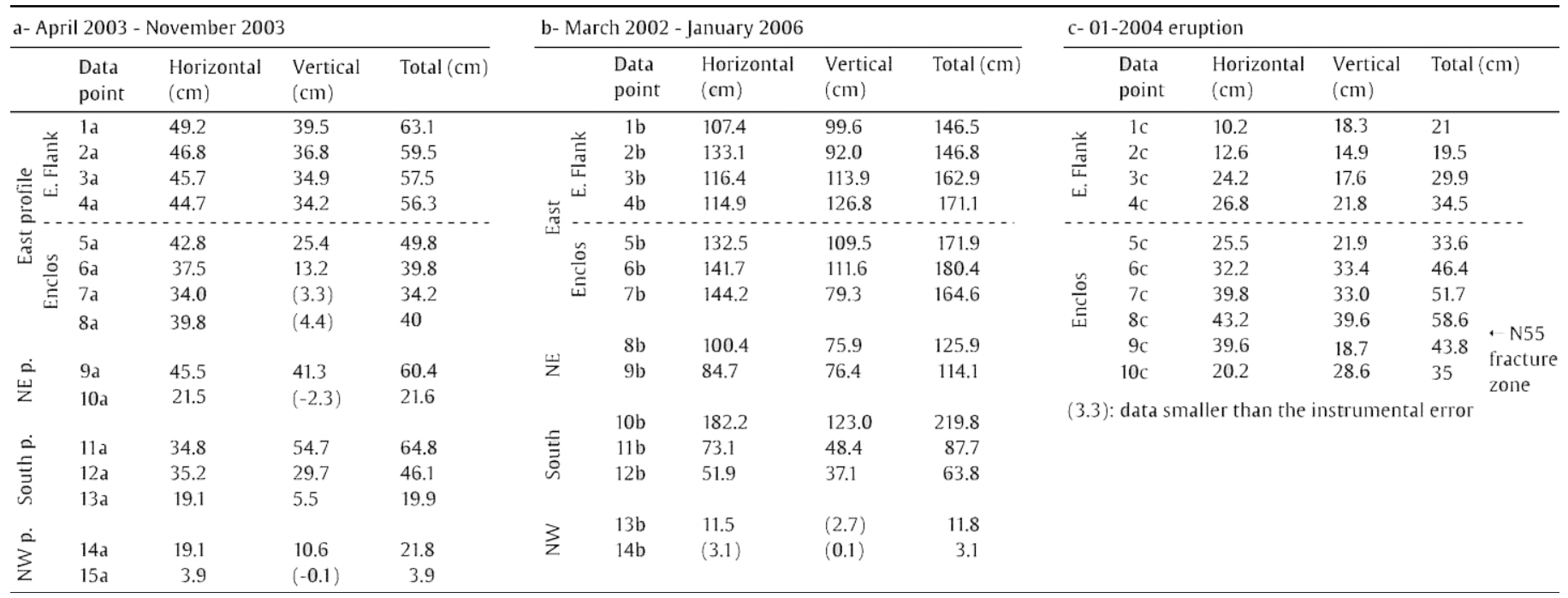

See Fig. 8 for the location of the data points.

\subsection{Co-intrusive displacements inferred from GPS}

At Piton de la Fournaise, dyke intrusions usually lead to an asymmetric deformation of the volcano characterised by a concentration of displacements east of the dykes (Lénat et al., 1989; Sigmundsson et al., 1999; Froger et al., 2004; Fukushima et al., 2005). GPS measurements carried out in 1981 and 1995 indicate that the eastern part of the cone summit experienced a 1.5-2-m eastward displacement during this period, whereas the western half remained stable (Briole et al., 1998). A denser GPS network composed of about 80 stainless steel benchmarks cemented around the crater, on the flanks and at the base of the summit cone was installed by the Piton de la Fournaise Volcano Observatory in order to better constrain co-intrusive deformation of the edifice. Since 2002, this network was repeatedly measured after each eruption. The location of each benchmark was determined with respect to a reference receiver situated north of the Enclos caldera. Sampling-rate of both receivers was of $1 \mathrm{~s}$ and benchmark locations were recorded during a 7-min stop on each.

As demonstrated above, between 1981 and 2007, dykes intruding the central cone followed the N120 rift zone, and the northern and southern segments of the N25-30 rift zone, in roughly the same proportion. Between April 2003 and November 2003, 3 eruptions and 1 intrusion occurred at the summit and along each rift zone, making the co-intrusive deformation of this period representative of the general behaviour during summit and proximal eruptions. GPS data clearly show the deformation decoupling between the eastern and western parts of the cone (Fig. 7a). West of a N-S decoupling axis located between Bory and Dolomieu, displacements are small at the summit $(<22 \mathrm{~cm})$ and negligible at the base of the cone and in the Enclos (Table 1). East of the axis, displacements rotate from a northeastward to a south-eastward motion from north to south, showing an average eastward motion of the eastern half of the central cone. Total displacement values of the summit are three times larger than in the West. GPS data reveal that vertical displacements are restricted to the cone, reaching a maximum at the summit. In contrast, both the cone and the proximal part of the Enclos caldera floor experience significant outward horizontal displacements. Finally, it is interesting to note that the northern and western flanks present a steady decrease of displacement values, whereas the south-east and east flanks are characterised by a step wise decrease, correlated with variations of the topography. For the E flank, the GPS data located in the steepest part (data points 1a to 4a in Table 1a and Fig. 7a) indicate a slight decrease of vertical displacements, i.e., between 39.5 and $34.2 \mathrm{~cm}$, whereas they sharply decrease from 24.2 to $3.3 \mathrm{~cm}$ over the same distance in the Enclos floor (data points 5a to 7a).

As a consequence, the recurrent dyke intrusions up to the summit and along the intra-cone segments of the N25-30 and N120 rift zones lead to heterogeneous growth of the central cone. Between April and November 2003, the cone underwent a very slight steepening of the western flank ( $\approx 4 \times 10^{-3 \circ} / \mathrm{yr}$ ), and a significant inflation of the eastern part, leading to a steepening of the south and east flanks $\left(\approx 1.5 \times 10^{-20}\right.$ / yr). Moreover, GPS data suggest that each N55 and N150 trending steep slope zone undergoes a homogeneous deformation. This overall deformation pattern inferred for the period between April 2003 and November 2003 fully agrees with the slope change determined by Fukushima (2005) between March 1998 and June 2000, during which 5 eruptions occurred along the $\mathrm{S}$ and $\mathrm{N}$ segments of the N25-30 rift zone and along the N120 rift zone. The striking similarities between the two different periods suggest a relatively constant mode of deformation of the cone when summit and proximal eruptions occur.

Most of the deformation determined for the period between March 2002 and January 2006 is similar to that of April to November 2003 in terms of (i) decoupling between the western and eastern parts and (ii) and progressive decrease of displacement amplitudes from the top to the base of the cone in the north, southwest and west flanks (Fig. 7b). It only differs in one point, which is the regular increase of total displacement values from 146.5 to $180.4 \mathrm{~cm}$ between the eastern part of the summit and the Enclos floor (Table 1b). Contrary to the periods between March 1998 and June 2000 and between April 2003 and November 2003, during which only summit and proximal eruptions occurred, the period between March 2002 and January 2006 was characterised by summit, proximal and also 3 distal eruptions in the Plaine des Osmondes (see Fig. 1 for location). The displacement pattern related to one of these eruptions, in January 2004, suggests that the progressive increase of displacements when going east of the summit is induced by distal intrusions toward the Plaine des Osmondes (Fig. 7c and Table 1c). Moreover, GPS data related to the January 2004 distal eruption indicate the existence of different displacement domains separated by the N55 deformation zone described above. The N55 fracture zone limits a differential uplift, which is twice as high west of the fracture zone as east.

In summary, our data clearly show two different co-intrusive modes of deformation. The cumulated deformation related to summit 
a

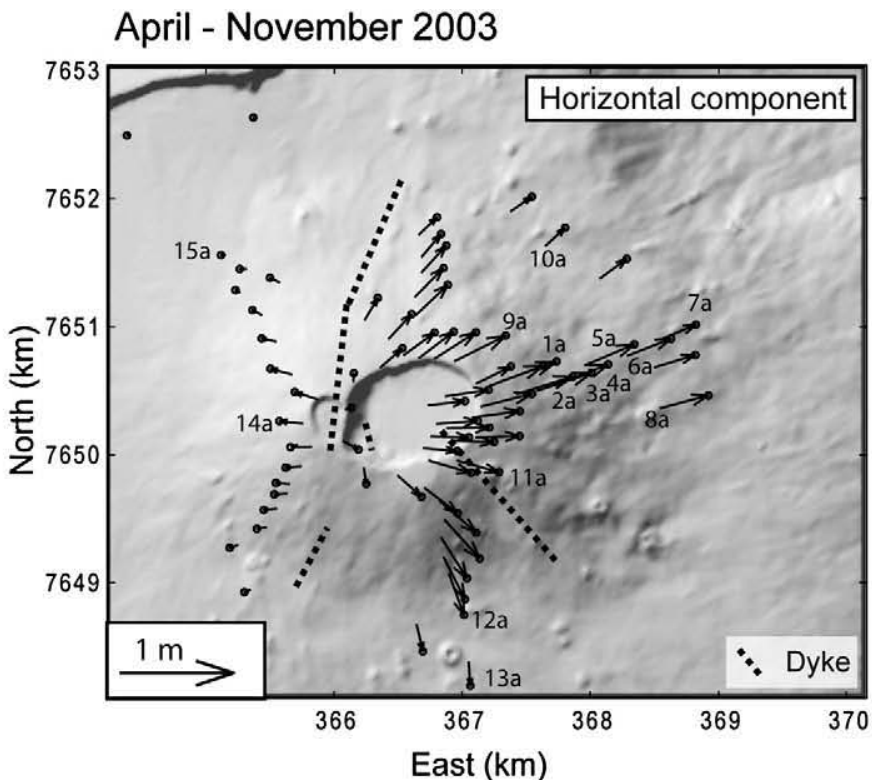

b

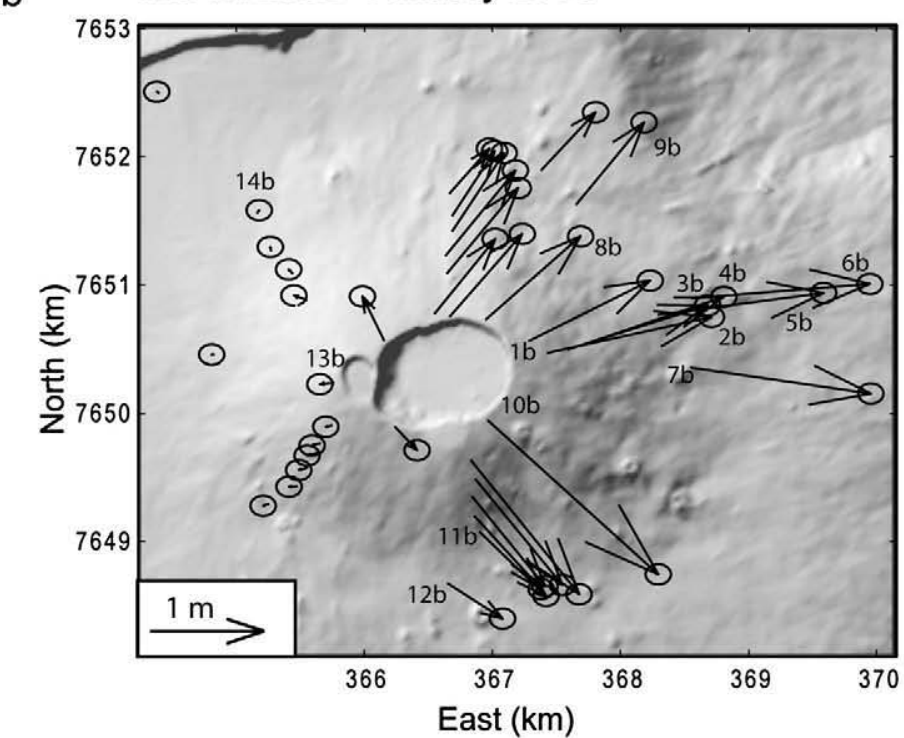

C January 2004

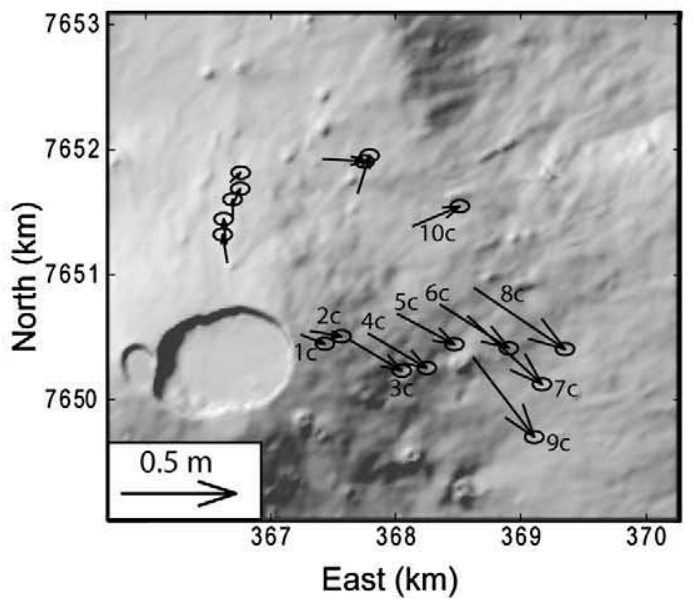

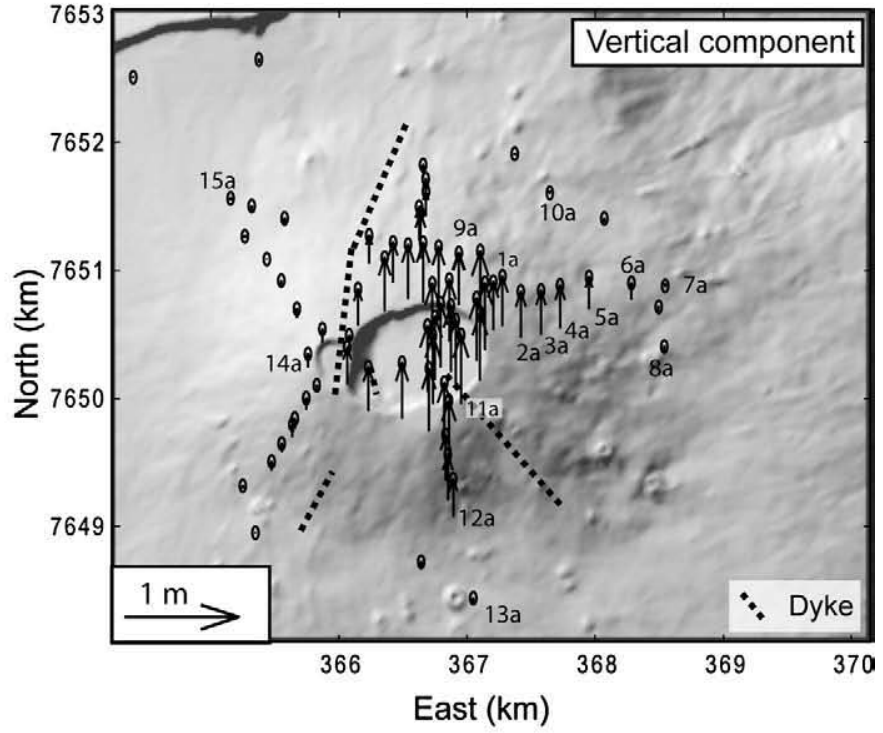
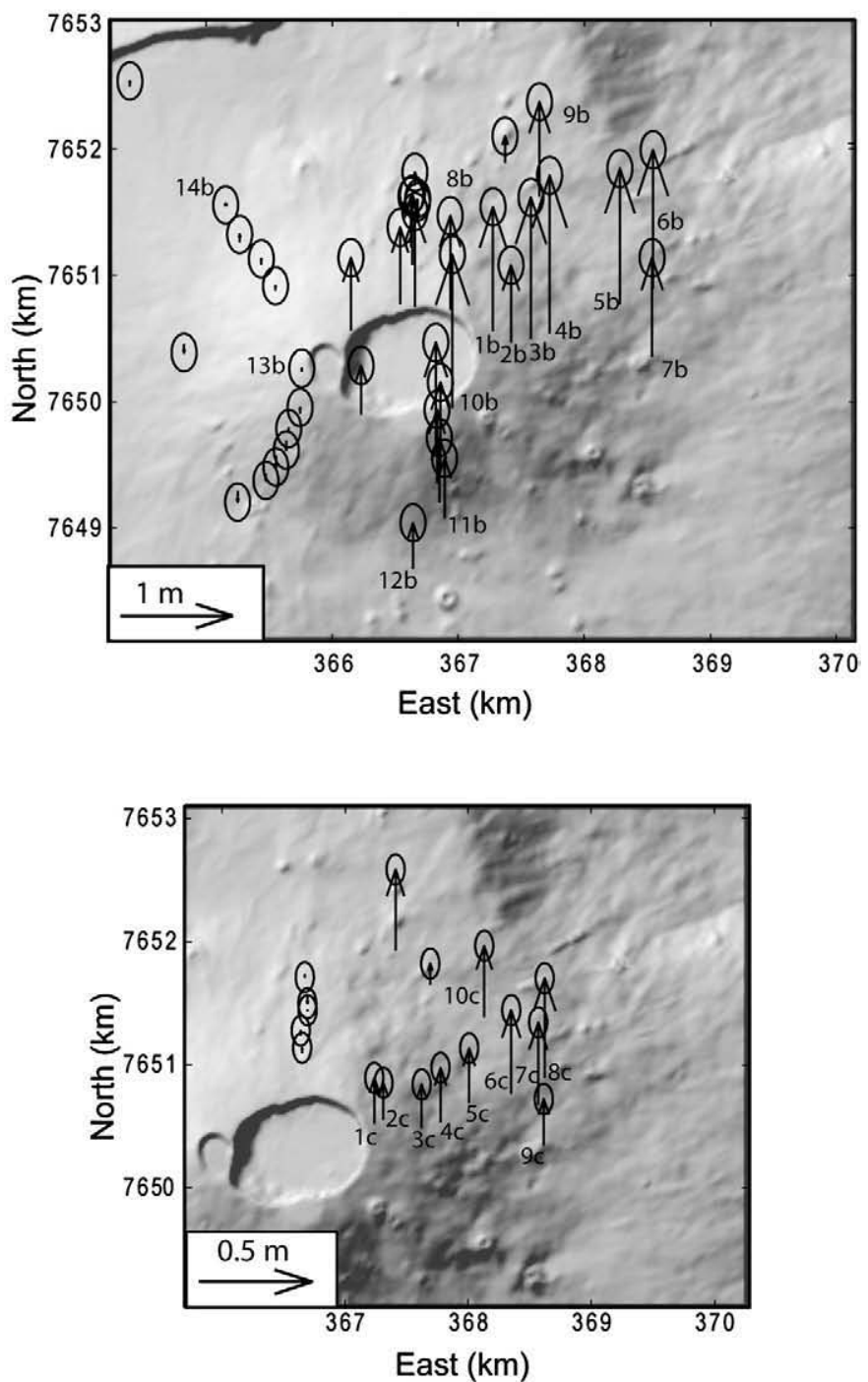

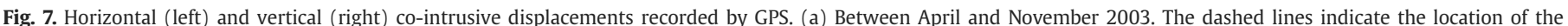
dykes. (b) Between March 2002 and January 2006. (c) During the January 2004 eruption. Coordinates in UTM WGS84 (zone 40S). 

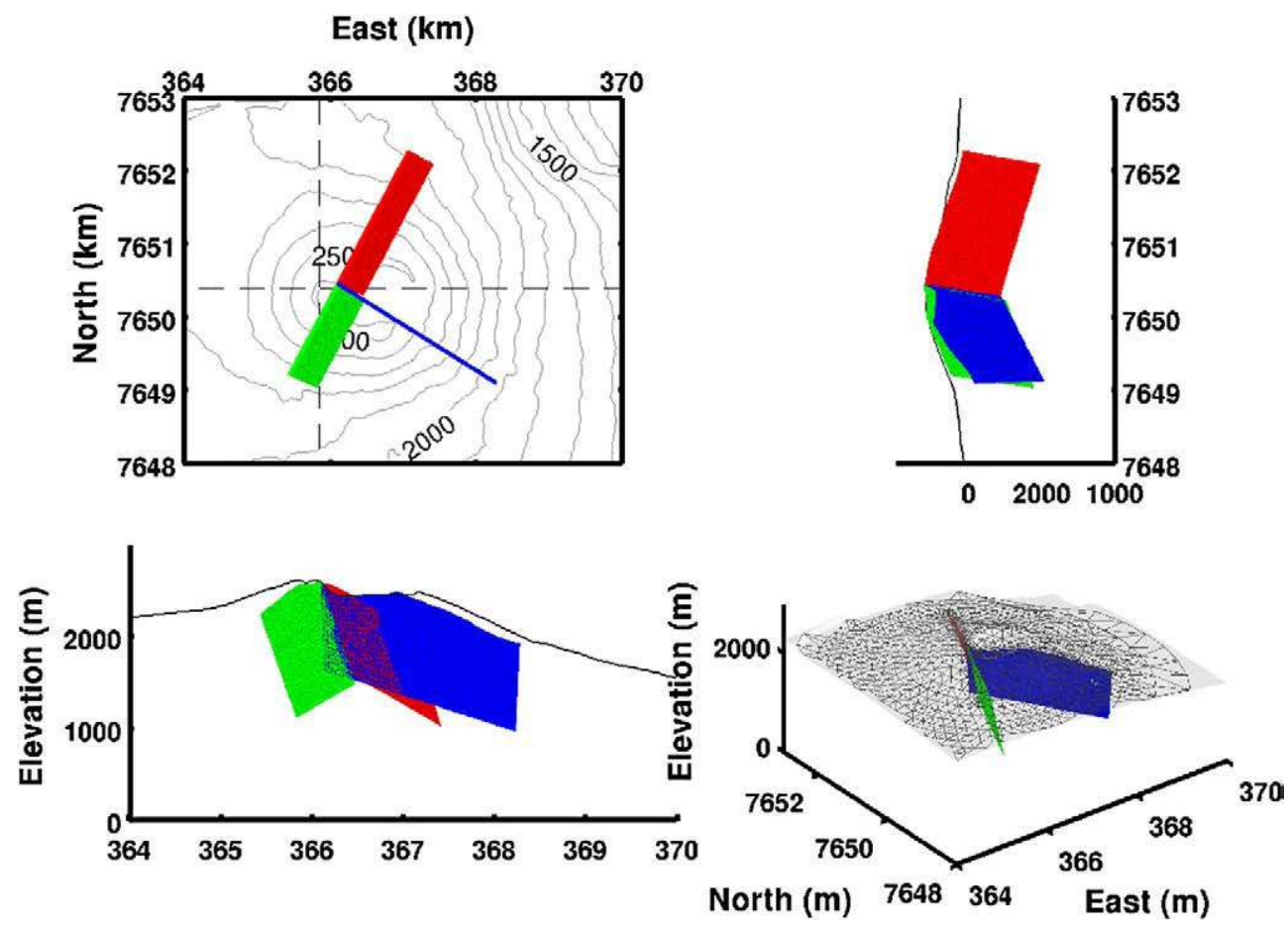

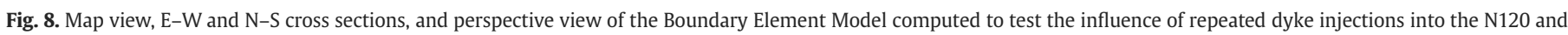

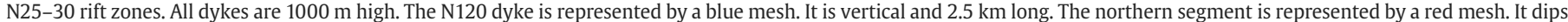

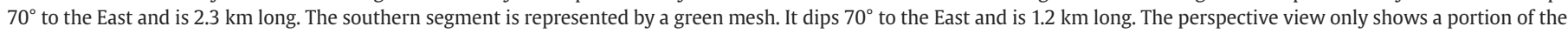
surface of the topography mesh, which extends five times further than shown.

and proximal intrusions is centred on the summit craters and is mostly restricted to the central cone. In contrast, the distal intrusions led to a widespread deformation, the limits of which cannot be determined with the current GPS network.

\subsection{Modelling of co-intrusive deformations}

We use a three-dimensional boundary element method (Cayol and Cornet, 1997) to investigate: (1) the injection-related endogenous growth of the central cone; (2) the interaction between dyke injections and fractures; and (3) stress changes due to dyke injection along the northern and southern segments of the N25-30 rift zone. Models consider an elastic medium. Young's modulus is $5 \mathrm{GPa}$ and Poisson ration is 0.25 (Cayol and Cornet, 1998). For the modelling, a mesh of the topography is constructed from a Digital Elevation Model of the volcano (Fig. 8). This mesh is dense close to the deformation sources and coarse further away. In order to limit errors caused by the finite extension of the ground surface mesh, its extension is chosen to be 5 times the source dimensions.

Three rift zone dykes were modelled, two along the N25-30 rift zone, to the North and to the South of the summit cone, and one along the N120 rift zone, east of the summit cone. Length of the dykes, heights and dips (Fig. 8) are typical of intrusions in rift zones (Sigmundsson et al., 1999; Froger et al., 2004; Fukushima et al., 2005; Peltier et al., 2007, 2008). The overpressure of the dykes is assumed to be $3 \mathrm{MPa}$, leading an average dyke opening of $2.3 \mathrm{~m}$ at the surface. As Piton de la Fournaise eruptions typically correspond to average dyke openings of $30 \mathrm{~cm}$ at the surface, these models are representative of more than 20 successive dyke intrusions, a number similar to the amount of intrusions that occurred between 1998 and 2007. Models show that dyke intrusions trigger an asymmetric deformation of the central cone (Fig. 9a). Flanks steepen east of the N25-30 rift zone of around $0.05^{\circ}$ and do not significantly change in the cone's western half. Only the summit part located north of Dolomieu and Dolomieu itself flatten. It is worth noting that the N150-160 fracture zone, which shows predominant extensional deformation, is located at the transition between domains showing contrasting deformation, i.e. increasing and decreasing slopes (Fig. 9b).

We computed changes of Coulomb stresses on N55 vertical faults in order to investigate the influence of intrusions in the N25-30 and N120 rift zones on the N55 fractures network. Changes of Coulomb stress $(\Delta S)$ depend on normal and shear stress changes at given fault plane orientations for a given slip directions. They are defined by $\Delta S=\Delta \tau-\mu^{\prime} \Delta \sigma$ (King et al., 1994), where $\Delta \tau$ is the shear stress change on a given failure plane (positive in the direction of fault slip), $\Delta \sigma$ is the change in normal stress on the plane (positive in compression) and $\mu^{\prime}$, the apparent coefficient of friction, includes the effect of pore pressure changes. Here, we set $\mu^{\prime}=0.4$, corresponding to laboratory values and small fluid pressure. Positive values of Coulomb stress changes bring faults closer to failure whereas negative values inhibit failure. We considered Coulomb stress changes induced by single dyke intrusion in each segment of the rift zones and by combined intrusions (Fig. 10). Dyke injections in the northern segment of the N25-30 rift zone promote right-lateral fault slip in the area of the N55-65 fractures, whereas injections in the southern segment of the N25-30 rift zone and in the N120 rift zone encourage left-lateral slip in the N55-65 fracture zone. Combinations of injections in the northern and southern segments of the N25-30 rift zone as well as in the N120 rift zone favour right lateral slip of N55 faults located $1 \mathrm{~km}$ East of Dolomieu crater.

Coulomb stress changes on optimally oriented vertical planes were also calculated to determine whether a N55 fault zone could result from repeated rift zone intrusions. Following Cayol and Cornet (1998), we assumed a roughly isotropic regional stress in the horizontal plane. Models reveal that one kilometre east of Dolomieu the direction of the optimally oriented planes is consistent with the observed N55-65 lineaments (Fig. 11). It suggests that failure can be reached along N55-65 trending faults. However, the moderate Coulomb stress changes in the area of the N55-65 fracture zone suggest that stresses related to repeated dyke injections are probably not important enough to create faults.

Finally, computations were carried out to unravel principal stress variations due to repeated injections in the northern and southern 
a

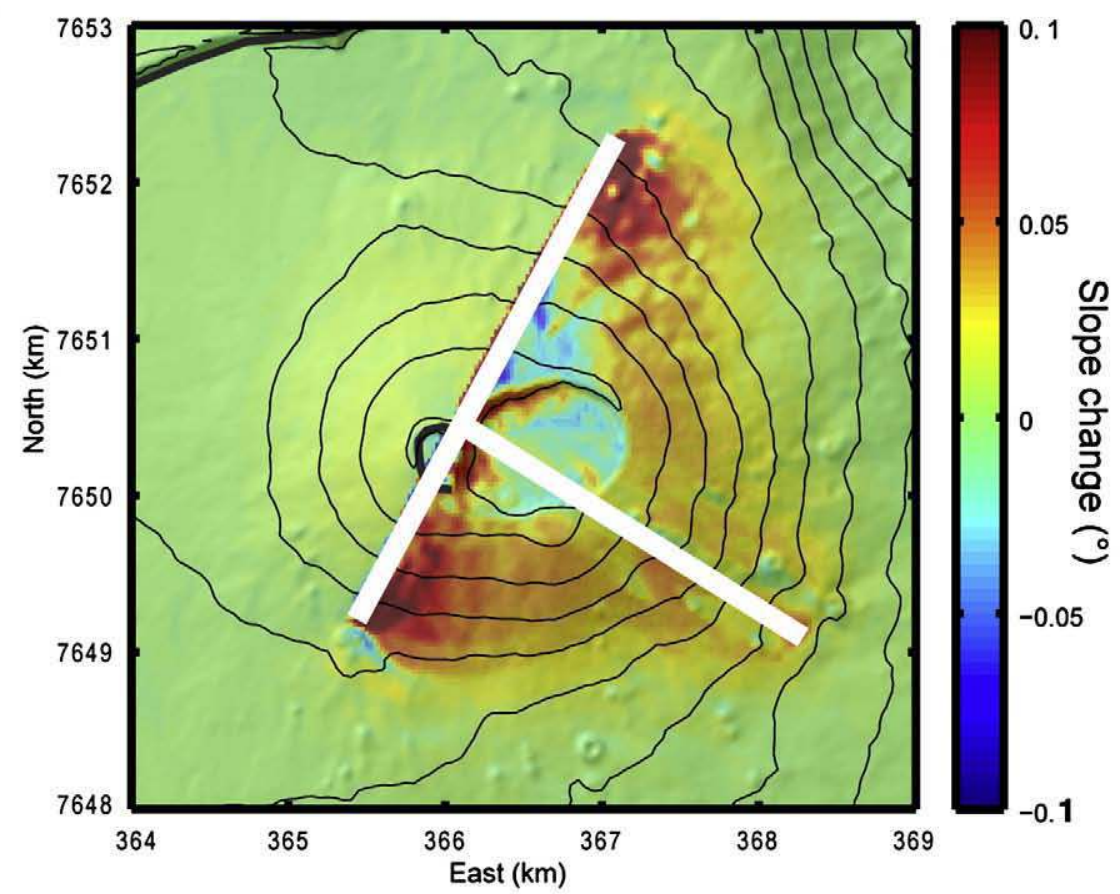

b

370

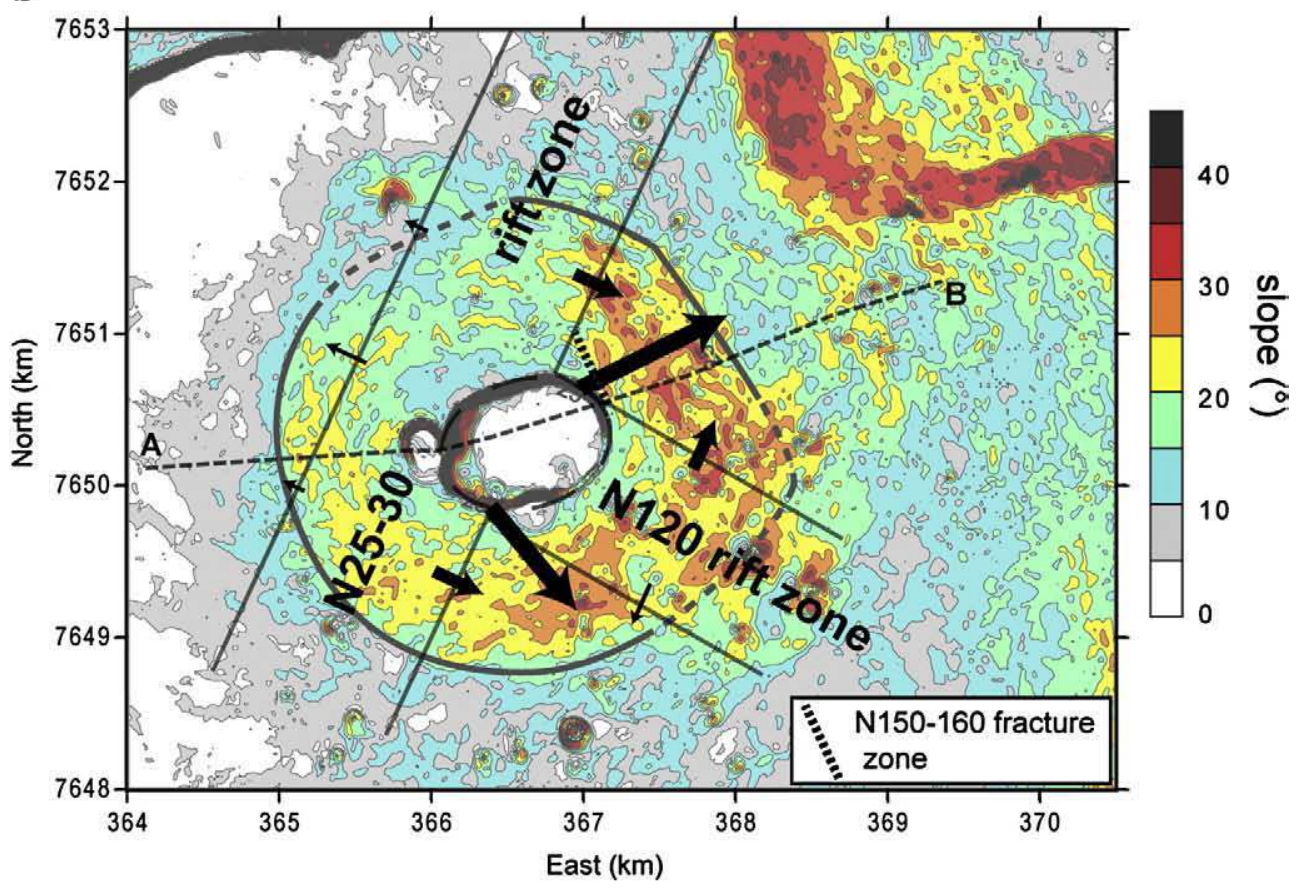

C

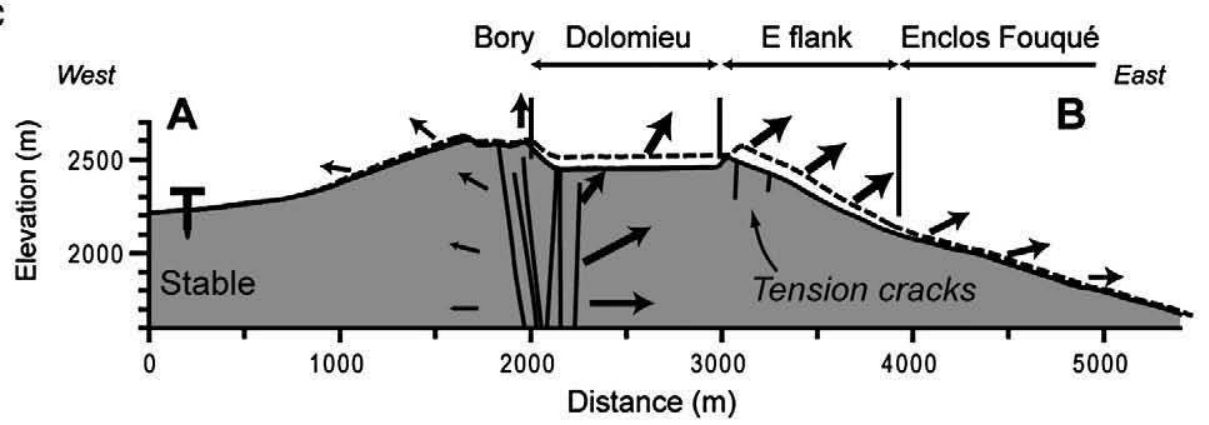

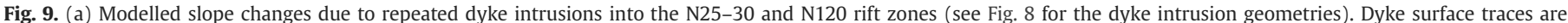

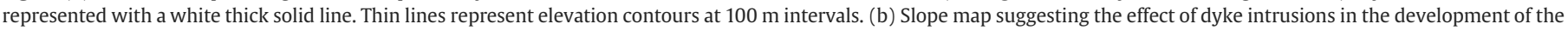
eastern and south-eastern steep flanks. (c) E-W cross section presenting the outward inflation of the cone's eastern half. 

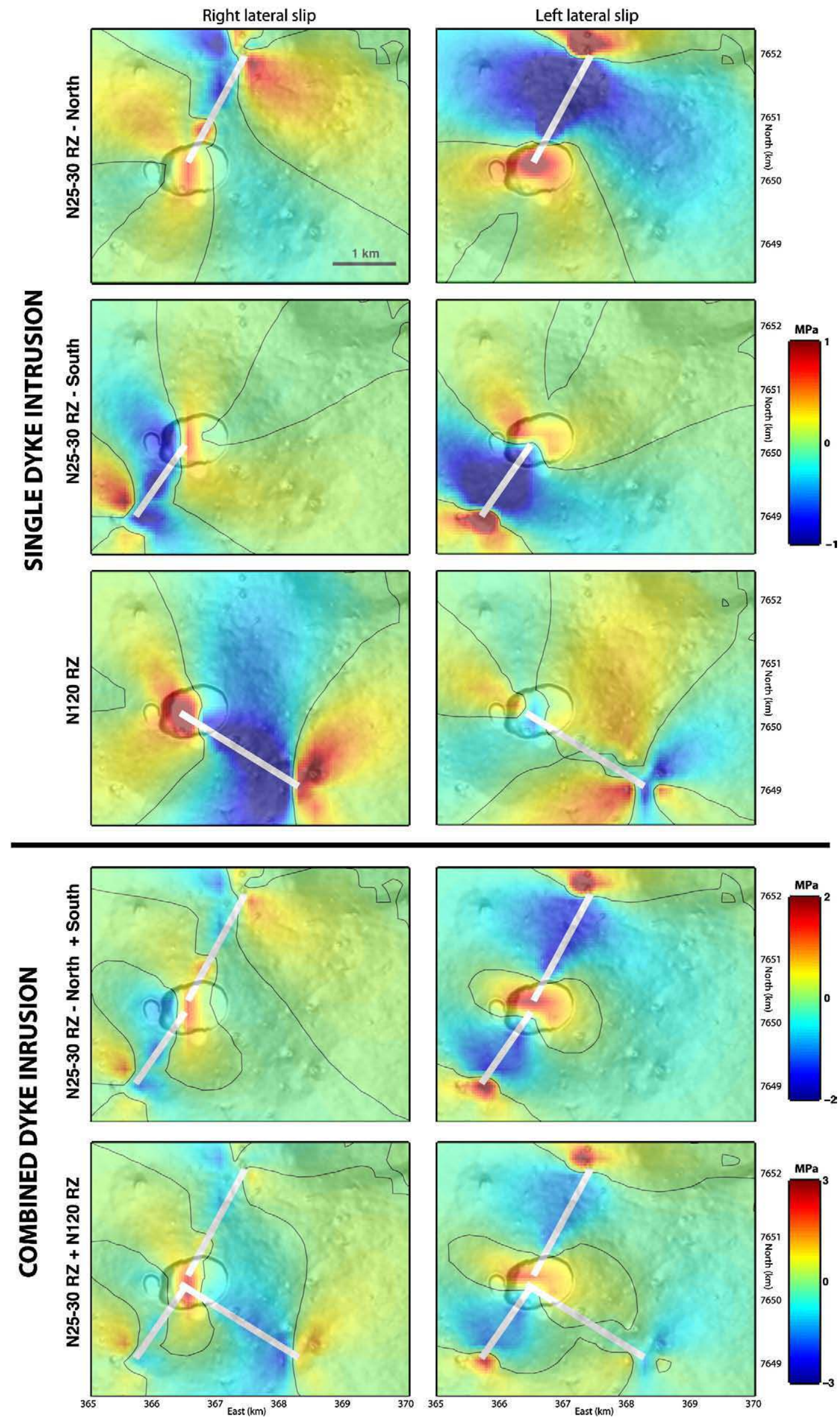

Fig. 10. Coulomb stress changes (Mpa) at a 1500 m elevation induced on N55 vertical faults by intrusions in the N25-30 and N120 rift zones (see Fig. 8 for the dyke intrusion geometries). Stress changes for right-lateral (left column) and left lateral (right column) slip are compared. Surface traces of the intruded dykes are shown as bold white lines. Null Coulomb stress changes are indicated by a light black line. 


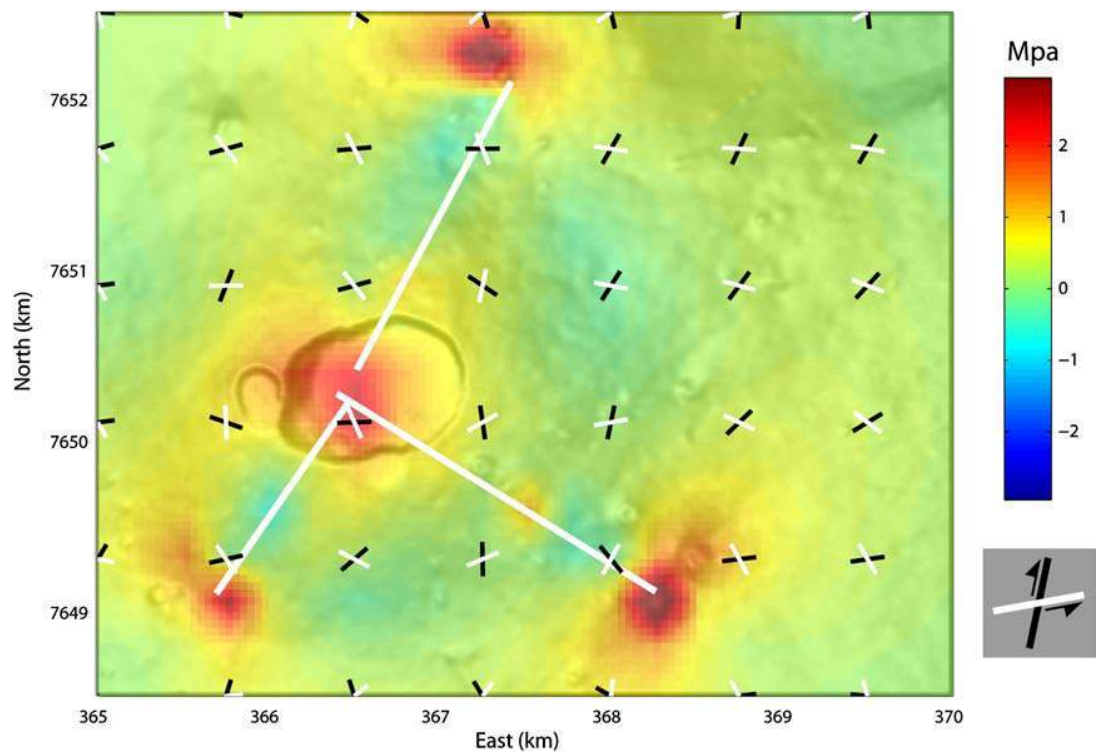

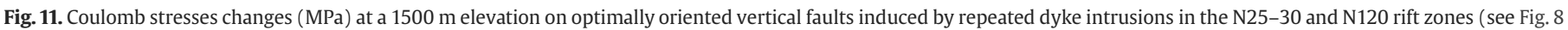

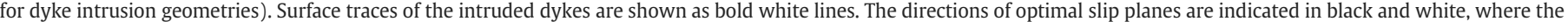
black and white colours indicate opposite slip sense.

segments of the N25-30 rift zone. Dyke propagation is controlled by the distribution of the total stress $\sigma^{t}$, which corresponds to $\sigma^{t}=\Delta \sigma+\sigma^{r}$, where $\Delta \sigma$ is the stress change due to magma injections and $\sigma^{r}$ is the pre- existing regional stress. The pre-existing regional stress being quantitatively unassessable, we solely determined the stress variations caused by dyke intrusions. Fig. 12a reveals that minimum principal stresses a

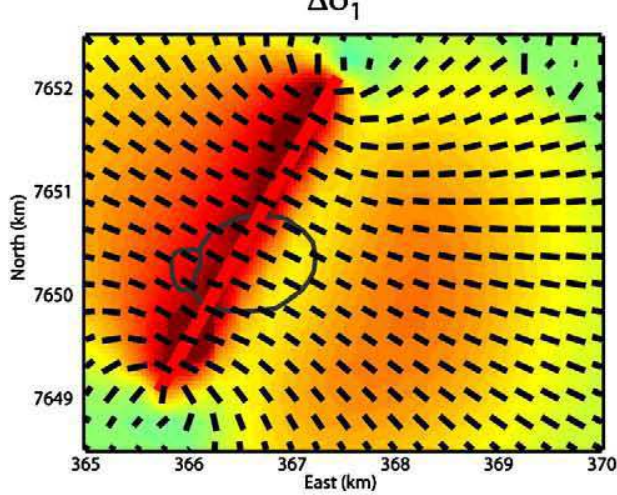

$\Delta \sigma_{2}$

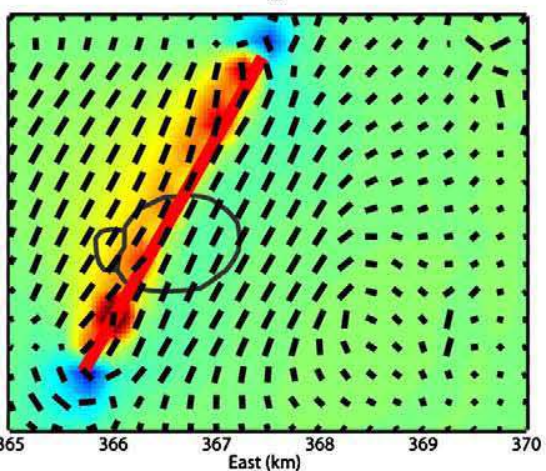

$\Delta \sigma_{3}$

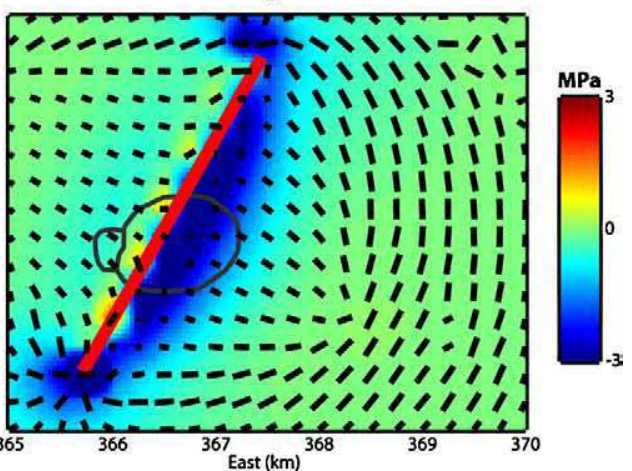

b

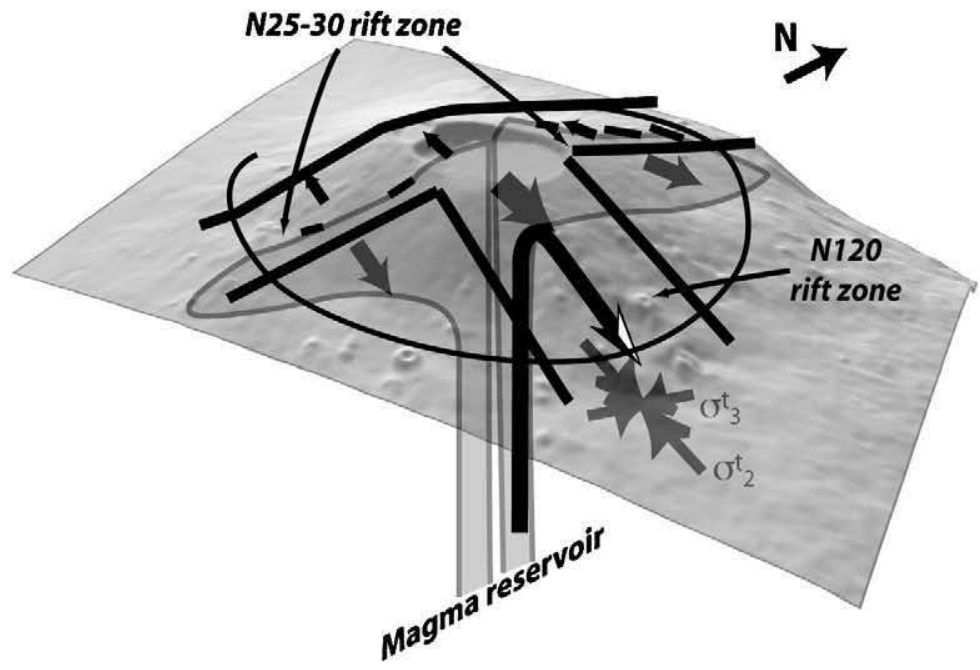

Fig. 12. (a) Principal stress changes $\Delta \sigma$ corresponding to repeated magma injections in the northern and southern segments of the N25-30 rift zone (see Fig. 8 for dyke intrusion geometries). $\Delta \sigma_{1}, \Delta \sigma_{2}$ and $\Delta \sigma_{3}$ correspond to the maximum, intermediate and minimum principal stress changes, respectively. (b) Interpretative sketch of the short, narrow N120 rift zone as resulting from the stress accumulation induced by recurrent intrusion along the N25-30 rift zone. 
changes, $\Delta \sigma_{3}$, are subvertical and parallel to the rift zone, while intermediate principal stresses changes, $\Delta \sigma_{2}$, are subhorizontal and parallel to the rift dyke (Fig. 12a). Letourneur et al. (2008) showed that the maximum principal stress $\sigma_{1}^{r}$ of the regional stress is vertical. Consequently, the total minimum principal stress $\sigma_{3}^{t}$ is probably horizontal and parallel to the N25-30 rift zone. As dykes intrude perpendicular to the total minimum principal stress, $\sigma_{3}^{t}$, the stress field induced by N2530 rift injections promotes N120 dyke injections (Fig. 12b).

\section{Discussion}

\subsection{Origin of the steep central cone}

The central cone of Piton de la Fournaise presents abnormally steep flanks for a basaltic volcano characterised by fissure eruptions and fluid lava flows. Annen et al. (2001) proposed that this morphology mainly results from predominant endogenous processes with recurrent thick and short intrusions originating from a small and shallow magma chamber, i.e., $200 \mathrm{~m}$ in diameter and located $500 \mathrm{~m}$ below the summit. Besides the disagreement between the input and natural data concerning the intrusion vs. eruption ratio (see the description in Section 1), the existence of a small shallow magma chamber is questionable. Indeed, the present deformation and seismic data suggest that the feeding dykes originate from a relatively deep magma chamber located at about sea level (Fukushima et al., 2005; Peltier et al., 2007, 2008). Furthermore, a small magma reservoir cannot explain the development of collapse structures such as the pre-Bory pit crater or the recent Dolomieu caldera, which are much larger than the hypothesized shallow magma chamber. Hence, we consider that the geometry of the central cone of Piton de la Fournaise does not result from the predominant endogenous processes described by Annen et al. (2001).

The April 2007 caldera collapse, which was coeval to the largest historical eruption deeply cut the central cone (Michon et al., 2007b; Urai et al., 2007). Observations of the caldera walls reveal that the cone predating the pre-Bory pit crater was essentially made of red scoria. It was subsequently covered by several tens of metres of thin lava flows. We propose that the scoria formations are evidences of the occurrence of a hidden strombolian pyroclastic cone below the upper thin lava flows. Strombolian cinder cones are usually characterised by slopes between $25^{\circ}$ to $30^{\circ}$, corresponding to the repose angle of the material (Porter, 1972; Wood, 1980). At Piton de la Fournaise, the east and southeast flanks of the central cone present such slope values. However, our GPS data, which clearly show progressive slope tilting during the recurrent intracone intrusions, suggest that part of the present slope values result from deformation processes. In the cone's western half, where the intrusionrelated deformation is limited, slope values are $10^{\circ}$ less than that of a classical cinder cone. Consequently, we interpret the present cone's geometry as resulting from a twofold evolution: a first period during which a cinder cone built up in the Enclos caldera floor, and a second period of predominant effusive activity overlapping and smoothing the initial cone geometry. A similar scenario was proposed to explain the steep morphology of Nyiragongo (Democratic Republic of Congo), where an initial explosive phase built up a steep cone and a lava lake activity with periodic overflowing veneered over the pyroclastic core (McDonald, 1972; Demant et al., 1994).

\subsection{Tectonic structures, co-intrusive deformation and rift zones}

Since 1981, all the structural analyses and geodetic measurements have shown that the eastern part of the central cone of Piton de la Fournaise was affected by an eastward motion (Bachèlery, 1981; Bachèlery et al., 1983; Delorme et al., 1989; Lénat et al., 1989; Zlotnicki et al., 1990; Briole et al., 1998; Sigmundsson et al., 1999; Froger et al., 2004; Fukushima et al., 2005; Carter et al., 2007; Peltier et al., 2007; Tinard, 2007). It has been first proposed that the entire eastern flank was involved in the deformation process (e.g., Bachèlery, 1981; Lénat et al.,
1989). The NE and SE rift zones were then considered as sinistral and dextral shear zones accommodating the lateral displacements of the volcano flank. However, recent GPS and radar interferometry data do not confirm such a general process and reveal that the deformation is directly related to dyke intrusions and concentrated around the central cone (Sigmundsson et al., 1999; Froger et al., 2004; Fukushima et al., 2005; Peltier et al., 2007). If the deformation pattern is well constrained with these types of data, little is known about the effect of recurrent intrusions in the development, or interaction with tectonic structures. Using field data collected around the summit collapse structures, i.e., the break-in-slope in the upper eastern flank, the fractures in the northern part of the N150-160 fracture zone and the conjugate-like geometry of the eruptive fissures, Carter et al. (2007) proposed an additional deformation process. According to these authors, the east flank of the central cone undergoes a progressive slump above a low strength layer, which is favoured by the recurrent intrusions along the N10 and N170 rift zones. We disagree with this model for the following reasons: (1) the fractures used to interpret the northern limit of the slump as a dextral shear zone do indicate a predominant extension, and correspond to a small part of a much longer extension structure, i.e., the N150-160 fracture zone; (2) the conjugate-like geometry of eruptive fissures results from two sets of eruptive fissures that are the common radial fissures and the long N55 trending fissures which develop in the east flank only; (3) the eastern base of the cone lacks any thrust fault or concentric compressional structures which would result from the slump; (4) The summit collapses disregarded, the deformation of the cone can be exclusively due to the dyke intrusions (Froger et al., 2004; Fukushima et al., 2005) and to a minor pre-eruptive inflation centred on the cone (Peltier et al., 2007, 2008).

This brief review reveals a lack of any global model in which both field observations and GPS or radar interferometry data are integrated. In the following, we propose to combine our multi-disciplinary data in order to determine: (i) the origin of the different tectonic structures (except for the summit collapses and the concentric fractures that are clearly linked to the magma withdrawal; Hirn et al., 1991; Longpré et al., 2007; Michon et al., 2007b; Michon et al., 2009-this issue); (ii) the role of the recurrent dyke intrusions in the morphology of the central cone; and (iii) the origin of the N25-30 and N120 rift zones and their consequences in the cone's evolution.

Our structural analysis of the central cone allows identification of two sets of tectonic structures. First, the different spatial distributions of flank fractures, eruptive fissures and dykes, especially in the western part of the cone (Figs. 4 and 6a), confirm that the development of the flank fractures does not correspond to the dyke-induced proximal deformation. In contrast, the superposition of the areas affected by these fractures and the co-intrusive deformation (Figs. 6a, 7a and 9a) suggests that the flank fractures are linked to the outward inflating tilting of the eastern part of the cone. Hence, we propose that the flank fractures, which are essentially characterised by extension, correspond to relatively shallow (maximum depth of few hundreds of metres) tension cracks that accommodate the endogenous growth during summit and proximal injections. The N20-30-trending fractures may result from the recurrent intrusions along the N25-30 rift zone whereas the N150-160 fractures may originate from the combined effect of intrusions along the N120 rift zone and the northern segment of the N25-30 rift zone (Fig. 9b and c).

The N55 fracture zone represents the second set of fractures. It is underlined by: (i) long, oblique eruptive fissures in the east flank of the cone (Fig. 4); (ii) a dense fracture network (Fig. 6c); (iii) striking lineaments on the DEM (Fig. 2c); and (iv) linear very steep slopes in the SE flank (Fig. 2b). As a whole, it corresponds to a 3-km-long structure, which is parallel to a larger tectonic structure that accommodated the collapse of the southern part of the Enclos caldera (Michon and Saint-Ange, 2008). Given the characteristics of the N55 fracture zone and the occurrence of volcano-tectonic events along or close to the lineaments (Sapin et al., 1996), we interpret it as a fault 
zone. The direction of the eruptive fissures in the eastern flank suggests that the fault zone controls the magma intrusion in the eastern part of the cone. Numerical models show that the N55-65 fault zone may be punctually reactivated by stresses related to dyke intrusions along the rift zones. They also indicate that the development of the fault zone does probably not result from intrusion-related stresses. Hence, we propose that the N55-65 fault zone is a tectonic structure inherited from the collapse of the Enclos Fouqué caldera, which is reactivated by the present-day dynamics of the magmatic system.

Our numerical models and GPS data indicate that the recurrent intrusions along the rift zones induce a heterogeneous deformation of the cone with (i) a significant inflation of the eastern part of the summit, (ii) the steepening of the southeast and east flanks, and (iii) very slight tilting of the western part (Fig. 9a). The superposition of the tilted zones and the N55 and N150 very steep slope zones strongly suggests that the slope value difference of about $5-10^{\circ}$ between the east and southeast flanks, and the west and north flanks results from the endogenous growth associated with intra-cone intrusions along the N25-30 and N120 rift zones (Fig. 9). Hence, if most of the present morphology of the central cone results from an exogenous growth, the specific morphology of the cone's eastern part is clearly due to endogenous processes.

The absence of any elongation along the N25-30 rift zone despite the substantial concentration of the intrusions along this structure contrasts with the morphologies of Hawaiian volcanoes and Karthala. Annen et al. (2001) showed that the geometry of the volcanoes was sensitive to the dyke length/source depth ratio. Volcanoes with ratios lower than 1 present an elongation perpendicular to the rift zones, whereas the elongation is parallel to the rift zones for ratios greater than 1 . For ratios close to one, the edifice remains circular despite the presence of radial rift zones. At Piton de la Fournaise, the mean dyke length along the northern and southern segments of the N25-30 rift zone and the source depth are of the same range (about $2000 \mathrm{~m}$ ). Then, the development of short dykes along the N25-30 and N120 rift zones may explain the subcircular geometry of the central cone.

The N25-30 and N120 rift zones were determined from the orientation and location of the dykes intruded since 1981. Michon et al. (2007a) proposed that the N25-30 rift zone, on which the cone built up, results from recurrent magma intrusions along a large, $10 \mathrm{~km}$ long structure in the Enclos caldera floor. The origin of the N120 rift zone is less constrained. It could be related to the regional N120-trending volcanic zone between Piton des Neiges and Piton de la Fournaise, the development of which has been interpreted as to be controlled by N120 crustal faults (Fig. 1; Chevalier and Vatin-Perignon, 1982; Michel and Zlotnicki, 1998; Michon et al., 2007a). However, the lack of any N120trending intrusions in the Enclos caldera, west of the N25-30 rift zone, and the contrasted geometries between the narrow rift zone east of the cone and the wide volcanic zone between Piton de la Fournaise and Piton des Neiges suggest a different origin of both structures. Our numerical modelling reveals that recurrent intrusions along the northern and southern segments of the N25-30 rift zone encourage intrusions in the N120 direction (Fig. 12a). Hence, we explain both the existence of the N120 rift zone East of the N25-30 rift zone and the lack of N120 trending dykes West of it, as a consequence of the general eastward dip of the N25-30 dykes (Fig. 12b). Such a geometry, which has been deduced from several sets of deformation data (Sigmundsson et al. 1999; Froger et al., 2004; Fukushima et al., 2005; Peltier et al., 2007, 2008), induces asymmetric deformations associated with much larger stress changes East of the N25-30 rift zone than West. The small length of the N120 rift zone may originate from a rapid decrease of the stress increase due to the N25-30 intrusions away from the plumbing system. This rift system, which has been determined from the summit and proximal intrusions is not fully connected with the NE and SE rift zones outside the Enclos caldera. Indeed, recent geophysical data (Brenguier et al., 2007) suggest that the NE and SE rift zones along which the distal eruptions occur are related to tectonic structures that are located below the magma chamber that feeds the summit and proximal eruptions.

\section{Conclusion}

Our work corresponds to the first analysis of the central cone of Piton de la Fournaise, which combines structural and GPS data, and numerical modelling. The main results can be summarised as follows:

(1) Similarly to Nyiragongo (Demant et al., 1994), the central cone is formed by a pyroclastic core overlapped by few tens of metres of lava flows. The general steep geometry of the cone does consequently not result from endogenous processes but from an initial phase during which a pyroclastic cone formed.

(2) The cone undergoes a contrasted co-intrusive deformation during summit and proximal eruptions along two N25-30 and N120 rift zones. Most of the co-intrusive displacements are concentrated in its eastern half where they induce a progressive outward inflation and the tilting of the eastern and southeastern flanks. A dense network of flank fractures, which differs from the eruptive fissures and the concentric fractures linked to the summit collapses, accommodate the progressive endogenous growth.

(3) The dynamics of the plumbing system also reactivates a N55 fault zone, which mainly controls magma intrusions in the eastern flank and decouples the deformation of the Enclos caldera floor during the north-eastward distal eruptions.

(4) The N25-30 rift zone is related to a large, 10-km-long fracture zone, whereas the short, narrow N120 rift zone results from a N120-trending stress accumulation west of the N25-30 rift zone, which guides magma intrusions.

\section{Acknowledgments}

The authors thank Ruth Andrew for improving an initial version of the manuscript. Two anonymous reviewers are kindly thanked for their constructive reviews, which helped to significantly improve the manuscript. This is IPGP contribution 2437.

\section{References}

Annen, C., Lénat, J.-F., Provost, A., 2001. The long-term growth of volcanic edifices: numerical modelling of the role of dyke intrusion and lava-flow emplacement. J. Volcanol. Geotherm. Res. 105, 263-289.

Bachèlery, P., 1981. Le Piton de la Fournaise (Ile de la Réunion). Etude volcanologique, structurale et pétrologique. PhD thesis, Univ. Clermont-Ferrand II, 215 pp.

Bachèlery, P., Chevallier, L., Gratier, J.P., 1983. Caractères structuraux des eruptions historiques du Piton de la Fournaise (Ile de la Réunion). C. R. Acad. Sci. Paris 296, 1345-1350.

Bory de Saint-Vincent, J.B.G.M., 1804. Voyage dans les quatre principales îles des Mers d'Afrique, Paris, XIII, 3 vol. in 8.

Brenguier, F., Shapiro, N.M., Campillo, M., Nercessian, A., Ferrazzini, V., 2007. 3-D surface wave tomography of the Piton de la Fournaise volcano using seismic noise correlations. Geophys. Res. Lett. 34, L02305. doi:10.1029/2006GL028586.

Briole, P., Bachèlery, P., Mc Guire, B., Moss, J., Ruegg, J.-C., Sabourault, Ph., 1998. Deformation at Piton de la Fournaise: evolution of the monitoring techniques and knowledge acquired in the last five years. In: Casal, R., Fytikas, M., Sigvaldasson, G., Vougioukalakis, G. (Eds.), Volcanic risk - the European laboratory volcanoes, European commission, EUR 18161 EN, pp. 467-474.

Carter, A., van Wyk de Vries, B., Kelfoun, K., Bachèlery, P., Briole, P., 2007. Pits, rifts and slumps: the summit structure of Piton de la Fournaise. Bull. Volcanol. 69, 741-756. doi:10.1007/s00445-006-0103-4.

Cayol, V., Cornet, F.H., 1997. 3D mixed boundary elements for elastostatic deformation field analysis. Int. J. Rock Mech. Min. Sci. 34, 275-287.

Cayol, V., Cornet, F.H., 1998. Three-dimensional modeling of the 1983-1984 eruption at Piton de la Fournaise volcano, Réunion Island. J. Geophys. Res. 103, 18,025-18,037.

Chevalier, L., Vatin-Perignon, N., 1982. Volcano-structural evolution of Piton des Neiges, Reunion Island, Indian Ocean. Bull. Volcanol. 45, 285-298.

Delorme, H., Bachèlery, P., Blum, P.A., Cheminée, J.L., Delarue, J.F., Delmond, J.C., Hirn, A., Lepine, J.C., Vincent, P.M., Zlotnicki, J., 1989. March 1986 eruptive episodes at Piton de la Fournaise volcano (Reunion Island). J. Volcanol. Geotherm. Res. 36, 199-208.

Demant, A., Lestrade, P., Lubala, R.L., Kampuzu, A.B., Durieux, J., 1994. Volcanological and petrological evolution of Nyiragongo volcano, Virunga volcanic field, Zaire. Bull. Volcanol. 56, 47-61.

Froger, J.-L., Fukushima, Y., Briole, P., Staudacher, Th., Souriot, Th., Villeneuve, N., 2004. The deformation field of the August 2003 eruption at Piton de la Fournaise, Reunion Island, mapped by ASAR interferometry. Geophys. Res. Lett. 31, L14601. doi:10.1029/2004GL020479. 
Fukushima, Y., 2005. Transferts de magma au volcan du Piton de la Fournaise determinés par la modélisation 3D des données d'interférométrie radar entre 1998 et 2000, PhD thesis, Université Clermont-Ferrand II, 149 pp. http://tel.archivesouvertes.fr/tel-00011582.

Fukushima, Y., Cayol, V., Durand, P., 2005. Finding realistic dike models from interferometric synthetic aperture radar data: The February 2000 eruption at Piton de la Fournaise. J. Geophys. Res. 110, B03206. doi:10.1029/2004JB003268.

Hirn, A., Lépine, J.C., Sapin, M., Delorme, H., 1991. Episodes of pit-crater collapse documented by seismology at Piton de la Fournaise. J. Volcanol. Geotherm. Res. 47, 89-104.

King, G.C.P., Stein, R.S., Lin, J., 1994. Static stress changes and the triggering of earthquake. Bull. Seism. Soc. Am. 84, 935-953.

Lénat, J.F., Bachèlery, P., 1990. Structure and dynamics of the central zone of Piton de la Fournaise volcano. In: Lénat, J.-F. (Ed.), Le volcanisme de la Réunion, Monographie. Cent. De Rech. Volcanol, Clermont Ferrand, pp. 257-296.

Lénat, J.F., Bachèlery, P., Bonneville, A., Hirn, A., 1989. The beginning of the 1985-1987 eruptive cycle at Piton de la Fournaise (La Réunion); New insights in the magmatic and volcano-tectonic systems. J. Volcanol. Geotherm. Res. 36, 209-232.

Letourneur, L., Peltier, A., Staudacher, Th., Gudmundsson, A., 2008. The effects of rock heterogeneities on dyke paths and asymmetric ground deformation: the example of Piton de la Fournaise (Réunion Island). J. Volcanol. Geotherm. Res. 173, 289-302.

Longpré, M.A., Staudacher, Th., Stix, J., 2007. The November 2002 eruption at Piton de la Fournaise volcano, La Réunion Island: ground deformation, seismicity, and pit crater collapse. Bull. Volcanol. 69, 511-525.

McDonald, G., 1972. Volcanoes. Prentice-hall, inc., Englewood cliffs, New Jersey. 510 pp.

Michel, S., Zlotnicki, J., 1998. Self-potential and magnetic surveying of La Fournaise volcano (Réunion Island: correlations with faulting, fluid circulation, and eruption. J. Geophys. Res. 103, 17845-17857.

Michon, L., Saint-Ange, F., 2008. The morphology of Piton de la Fournaise basaltic shield volcano (La Réunion island): characterization and implication in the volcano evolution. J. Geophys. Res. 113, B03203. doi:10.1029/2005JB004118.

Michon, L., Saint-Ange, F., Bachèlery, P., Villeneuve, N., Staudacher, Th., 2007a. Role of the structural inheritance of the oceanic lithosphere in the magmato-tectonic evolution of Piton de la Fournaise volcano (La Réunion Island). J. Geophys. 112, B04205. doi:10.1029/2006JB004598.

Michon, L., Staudacher, Th., Ferrazzini, V., Bachèlery, P., Marti, J., 2007b. April 2007 collapse of Piton de la Fournaise: a new documented example of caldera formation. Geophys. Res. Lett. 34, L21301. doi:10.1029/2007GL031248.

Michon, L., Villeneuve, N., Catry, Th., Merle, O., 2009. How summit calderas collapse on basaltic volcanoes: new insights from the April 2007 caldera collapse of Piton de la Fournaise, J. Volcanol. Geotherm. Res. doi:10.1016/j.jvolgeores.2008.11.003.
Naumann, T., Geist, D., 2000. Physical volcanology and structural development of Cerro Azul Volcano, Isabela Island, Galapagos: implications for the development of Galapagos-type shield volcanoes. Bull. Volcanol. 61, 497-514.

Nercessian, A., Hirn, A., Lépine, J.-C., Sapin, M., 1996. Internal structure of Piton de la Fournaise volcano from seismic wave propagation and earthquake distribution. J. Volcanol. Geotherm. Res. 70, 123-143.

Peltier, A., Staudacher, Th., Bachèlery, P., 2007. Constraints on magma transfers and structures involved in the 2003 activity at Piton de La Fournaise from displacement data. J. Geophys. Res. 112, B03207. doi:10.1029/2006JB004379.

Peltier, A., Famin, V., Bachèlery, P., Cayol, V., Fukushima, Y., Staudacher, Th., 2008. Cyclic magma storages and transfers at Piton de La Fournaise volcano (La Réunion Island) inferred from deformation and geochemical data. Earth. Planet. Sci. Lett. 270, 180-188. doi:10.1016/j.epsl.2008.02.042.

Porter, S.C., 1972. Distribution, morphology and size frequency of cinder cones on Mauna Kea volcano, Hawaii. Geol. Soc. Am. Bull. 83, 3607-3612.

Rowland, S.K., Garbeil, H., 2000. Slopes of oceanic basalt volcanoes. In: Mouginis-Mark P.J., Crisp, J.A., Fink, J.H. (Eds.), Remote sensing of active volcanism. AGU Monograph, vol. 116, pp. 223-247.

Sapin, M., Hirn, A., Lépine, J.-C., Nercessian, A., 1996. Stress, failure and fluid flow deduced from earthquakes accompanying eruptions at Piton de la Fournaise volcano. J. Volcanol. Geotherm. Res. 70, 145-167.

Sigmundsson, F. Durand, $\mathrm{Ph}$., Massonnet, D. 1999. Opening of an eruptive fissure and seaward displacement at Piton de la Fournaise volcano measured by RADARSAT satellite radar interferometry. Geophys. Res. Lett. 26, 533-536.

Tinard, P., 2007. Caractérisation et modélisation des déplacements du sol associés à l'activité volcanique du Piton de la Fournaise, île de La Réunion, à partir de données interférométriques. Août 2003 - Avril 2007, Ph.D. Thesis, Univ. Blaise Pascal, 334p. http://tel.archives-ouvertes.fr/action/open_file.php?url=http://tel archives-ouvertes.fr/docs/00/27/15/39/PDF/PhD_Tinard.pdf\&docid=271539.

Urai, M., Geshi, N., Staudacher, T., 2007. Size and volume evaluation of the caldera collapse on Piton de la Fournaise volcano during the April 2007 eruption using ASTER stereo imagery. Geophys. Res. Lett. 34, L22318. doi:10.1029/2007GL031551.

Wood, C.A., 1980. Morphometric evolution of cinder cones. J. Volcanol. Geotherm. Res. 7 $387-413$.

Zlotnicki, J., Ruegg, J.C., Bachèlery, P., Blum, P.A., 1990. Eruptive mechanisms on Piton de la Fournaise volcano associed with the December 4, 1983, and January 18, 1984 eruptions from ground deformation monitoring and photogrammetric surveys. J. Volcanol. Geothem. Res. 40, 197-217. 